\title{
Production of Fuel-Like Fractions by Fractional Distillation of Bio-Oil from Açaí (Euterpe oleracea Mart.) Seeds Pyrolysis
}

\author{
Douglas Alberto Rocha de Castro ${ }^{1}\left(\mathbb{D}\right.$, Haroldo Jorge da Silva Ribeiro ${ }^{1}$, Lauro Henrique Hamoy Guerreiro ${ }^{2}$, \\ Lucas Pinto Bernar ${ }^{1}$, Sami Jonatan Bremer ${ }^{3}$, Marcelo Costa Santo ${ }^{1}$, Hélio da Silva Almeida ${ }^{4,5}$, \\ Sergio Duvoisin, Jr. ${ }^{6}$, Luiz Eduardo Pizarro Borges ${ }^{7}$ and Nélio Teixeira Machado ${ }^{1,4, *}$
}

1 Graduate Program of Natural Resources Engineering of Amazon, Rua Corrêa N ${ }^{\circ} 1$, Campus Profissional-UFPA, Belém 66075-110, Brazil; douglascastro87@hotmail.com (D.A.R.d.C.); harold_lr@hotmail.com (H.J.d.S.R.); lucas.bernar7@gmail.com (L.P.B.); marcelo.santos@ufra.edu.br (M.C.S.)

2 Graduate Program of Chemical Engineering, Rua Corrêa N ${ }^{\circ}$ 1, Campus Profissional-UFPA, Belém 66075-110, Brazil; guerreirolauro@hotmail.com

3 Hochschule für Technik und Wirtschaft Berlin, Wilhelminenhofstrasse 75A, 12459 Berlin, Germany; jonatan-bremer-berlin@web.de

4 Faculty of Sanitary and Environmental Engineering, Rua Corrêa № 1, Campus Profissional-UFPA, Belém 66075-900, Brazil; helioalmeida@ufpa.br

5 Graduate Program of Civil Engineering, Rua Corrêa N ${ }^{\circ}$ 1, Campus Profissional-UFPA, Belém 66075-110, Brazil

check for updates

Citation: Rocha de Castro, D.A.; da Silva Ribeiro, H.J.; Hamoy Guerreiro, L.H.; Pinto Bernar, L.; Jonatan Bremer, S.; Costa Santo, M.; da Silva Almeida, H.; Duvoisin, S., Jr.; Pizarro Borges, L.E.; Teixeira Machado, N.

Production of Fuel-Like Fractions by Fractional Distillation of Bio-Oil from Açaí (Euterpe oleracea Mart.) Seeds Pyrolysis. Energies 2021, 14, 3713. https://doi.org/10.3390/en14133713

Academic Editors: Andrea Di Carlo and Elisa Savuto

Received: 8 February 2021

Accepted: 26 April 2021

Published: 22 June 2021

Publisher's Note: MDPI stays neutral with regard to jurisdictional claims in published maps and institutional affiliations.

Copyright: (c) 2021 by the authors. Licensee MDPI, Basel, Switzerland. This article is an open access article distributed under the terms and conditions of the Creative Commons Attribution (CC BY) license (https:// creativecommons.org/licenses/by/ $4.0 /)$.
6 Faculty of Chemical Engineering-UEA, Avenida Darcy Vargas Nº. 1200, Manaus 69050-020, Brazil; sjunior@uea.edu.br

7 Laboratory of Catalyst Preparation and Catalytic Cracking, Section of Chemical Engineering-IME, Praça General Tibúrcio No. 80, Rio de Janeiro 22290-270, Brazil; luiz@ime.eb.br

* Correspondence: machado@ufpa.br; Tel.: +55-91-984-620-325

Abstract: This work investigates the effect of production scales (laboratory, bench, and pilot) by pyrolysis of Açaí (Euterpe oleracea Mart.) seeds at $450{ }^{\circ} \mathrm{C}$ and 1.0 atmosphere, on the yields of reaction products and acid value of bio-oils. The experiments were carried out in batch mode using a laboratory scale reactor of $143 \mathrm{~mL}$, a bench scale reactor of $1.5 \mathrm{~L}$, and a pilot scale reactor of $143 \mathrm{~L}(\approx 1: 10: 1000)$. The bio-oil was obtained in pilot scale, fractionated by distillation to produce biofuel-like fractions. The distillation of bio-oil was carried out in a laboratory column. The physicalchemistry properties (density, kinematic viscosity, acid value, and refractive index) of bio-oils and distillation fractions were determined. The qualitative analysis was determined by FT-IR and the chemical composition by GC-MS. The pyrolysis showed bio-oil yields from 4.37 to 13.09 (wt.\%), decreasing with reactor volume. The acid value of bio-oils varied from 68.31 to $70.26 \mathrm{mg} \mathrm{KOH} / \mathrm{g}$. The distillation of bio-oil produced gasoline, light kerosene, and kerosene-like fuel fractions, and the yields were 16.16, 19.56, and 41.89 (wt.\%), respectively. The physical-chemistry properties of distillation fractions increase with temperature. The FT-IR analysis of bio-oils and distillation fractions identified the presence of functional groups characteristic of hydrocarbons (alkenes, alkanes, aromatics, and aromatics rings) and oxygenates (carboxylic acids, ketones, esters, ethers, alcohols, phenols). The GC-MS identified 48.24 (area.\%) hydrocarbons and 51.76 (area.\%) oxygenates in the bio-oil produced in bench scale and 21.52 (area.\%) hydrocarbons and 78.48 (area.\%) oxygenates in the bio-oil produced in pilot scale. The gasoline-like fraction was composed by 64.0 (area.\%) hydrocarbons and 36.0 (area.\%) oxygenates, light kerosene-like fraction by 66.67 (area.\%) hydrocarbons and 33.33 (area.\%) oxygenates, and kerosene-like fraction by 19.87 (area.\%) hydrocarbons and 81.13 (area.\%) oxygenates.

Keywords: Açaí; residual seeds; pyrolysis; bio-oil; distillation; gasoline; light kerosene; kerosenelike fuel

\section{Introduction}

Açaí (Euterpe oleracea Mart.) is a native palm of natural occurrence in tropical Central and South America [1]. The palm gives a dark-purple, berry-like fruit, clustered into 
bunches [2]. The fresh fruits are traditionally processed by crushing and/or extracting the pulp and skin with warm water to produce a thick, purple-colored beverage/juice or a paste [3,4]. The fruit is a staple food in rural and urban areas of the Amazon River estuary, particularly in the State Pará (Pará-Brazil), with great economic importance for both rural areas and at regional levels [5]. It has become one of the most important export products of the Amazon River estuary to other parts of Brazil [5], as well as overseas [6].

Of the total 1.228.811 tons/year of fruits produced by the State Pará, between 85\% [7] and $83 \%$ (wt.) [8] is a residue (Açaí seeds), thus producing between 1.019 .913 and 1.044.489 tons/year of a residue. The mechanical processing of Açaí fruits in nature produces around 175.7 tons residue/day in off-season crop and 448.0 tons residue/day in in-season crop in the metropolitan region of Belém (Pará-Brazil), posing a complex environmental problem of solid waste management $[9,10]$. The Açaí fruit is a small, dark-purple, berry-like fruit, almost spherical, weighing between 2.6 to $3.0 \mathrm{~g}$ [11], with a diameter around 10.0 and $20.0 \mathrm{~mm}$ [11], containing a large core seed that occupies almost $85 \%$ (vol.\%) of its volume [3]. Açaí fruit has an oily-fiber seed, rich in lignin-cellulose material [12-15].

Pyrolysis makes possible the use of low quality lignin-cellulosic material to produce not only bio-oils, but also gaseous fuels, and a carbonaceous rich solid phase, as reported in the literature [16-73]. Studies include biomass pyrolysis $[23,24,26,45,56,57,62,67,68]$, bio-oil chemical upgrading techniques [26,45,50], bio-oil physical-chemical properties $[21,25,26,28,34,35,43,57,62,63]$, as well as separation and/or purification processes to improve bio-oil quality [17-22,30-33,36-41,46-48,51,53,54,59-61,65,66,70-73].

The bio-oil produced by pyrolysis is a multicomponent liquid mixture presenting water, carboxylic acids, aldehydes, ketones, alcohols, esters, ethers, aliphatic hydrocarbons, aromatic hydrocarbons, anhydrous-sugars, furans, phenols derivatives, among others chemical functions $[16,17,20,38,44,47,48,53,60,61,73]$. In addition, its organic fraction has a wide distribution of polarity, molecular weight [47], as well as differences in thermophysical and transport properties of chemical compounds, as reported by the simulation of organic liquid compounds [74], posing challenges to the efficient separation and/or purification processes $[47,74]$.

In the last years, several thermal and physical separation processes were applied to remove oxygenates from biomass-derived bio-oils including molecular distillation [30,33,36-39,71], fractional distillation [17-21,40,41,46-48,53,59,60,66,70,72,73], liquid-liquid extraction $[22,31,61]$, and fractional condensation $[51,54,65]$. In addition, chemical methods such as catalytic upgrading of bio-oil vapors have been applied to improve bio-oil quality $[19,29,64]$.

The fractional distillation studies were carried out in micro/bench scale $[17,46,47]$, laboratory scale $[41,53,66,70,72,73]$, and pilot scale [21], under atmospheric [17,18,46$48,53,66,70,72,73]$, or under vacuum conditions [18,19,41,48,53]. Açaí seeds are the only fruit specie whose centesimal and elemental composition is completely different from wood biomass (aspen poplar wood, eucalyptus, maple wood, and softwood bark) [17-19,21,53], residues of cereal grains (corn Stover, rice Rusk) [41,46,47,66,70,72], jatropha curcas [46], and horse manure and switch-grass [53]. However, until the moment, no systematic study investigated the physicochemical properties (density, kinematic viscosity, refractive index, and acid value) and chemical composition of Açaí seeds bio-oil distillation fractions [73]. The fractional distillation studies are summarized as follows [21-23,25,45,50-52,57,70,72,73].

Adjaye et al. [21], investigated the distillation of aspen poplar wood high-pressure liquefaction bio-oil. High-pressure liquefaction was carried out at $5.0 \mathrm{MPa}$ and $360^{\circ} \mathrm{C}$, using $100 \mathrm{~g}$ of feed material $\left(\varnothing_{\text {Particle }} \sim 1.0 \mathrm{~mm}\right.$ ), $10 \mathrm{~g}$ of $\mathrm{Na}_{2} \mathrm{CO}_{3}, 500 \mathrm{~g}$ distilled $\mathrm{H}_{2} \mathrm{O}$, under $\mathrm{CO}$ atmosphere, and $2 \mathrm{~h}$ reaction time. The reaction liquid products consist of an organic (bio-oil) and an aqueous phase, showing a bio-oil yield of 30 (wt.\%), containing 1.5 (wt.\%) $\mathrm{H}_{2} \mathrm{O}$. The bio-oil distilled within the boiling temperature ranges $85^{\circ} \mathrm{C}<\mathrm{T}^{\mathrm{Boiling}}<250^{\circ} \mathrm{C}$, using $4.0 \mathrm{~g}$ of bio-oil. The distillations carried out at $85,115,140,165,175,190,200,220$, and $250{ }^{\circ} \mathrm{C}$. The yields of distillation fractions varied between 21.0 and $62.3(\mathrm{wt} . \%)$, while those of bottom products were between 37.7 and 79 (wt.\%). The content of hydrocarbons in the 
distillation fractions varied within the range 38.5 and 47.4 (area.\%), increasing between 85 and $175{ }^{\circ} \mathrm{C}$, reaching a maximum of 47.4 (area.\%) at $175^{\circ} \mathrm{C}$, decreasing between 175 and $250{ }^{\circ} \mathrm{C}$. The concentration of oxygenates lies in the range 43 and 56.6 (area.\%), showing a tendency to increase between 85 and $250{ }^{\circ} \mathrm{C}$, presenting a maximum of 56.6 (area.\%) at $250{ }^{\circ} \mathrm{C}$. In addition, the concentration of phenols in the distillation fractions increases with temperature. The GC-MS analysis of bio-oil identified 85 compounds including carboxylic acids (formic, acetic, and propionic acids), cyclic alcohols, aliphatic alcohols, aldehydes, ketones, aromatic hydrocarbons, aliphatic hydrocarbons, polycyclic hydrocarbons, unsaturated hydrocarbons, substituted furans, substituted phenols, and methoxy phenols (phenol, guaiacol, $p$-cresol, p-guaiacol, o-guaiacol, iso-eugenol, and catechol).

Carazza et al. [22] investigated the distillation of Eucalyptus tar, recovered from the carbonization retort process. The physical-chemical properties of Eucalyptus tar show a density of $1.180 \mathrm{~g} / \mathrm{cm}^{3}$ and viscosity of $87.17 \mathrm{~mm}^{2} / \mathrm{s}$, with an acidity of 8.70 (\% HAc). The distillation consists of a $3000 \mathrm{~L}$ boiler, coupled to a fractionation column of 04 stages, a reflux system, 2 condensers, a homogenization system (centrifuge pump), sample units, a collecting unit, and a vacuum system. The Eucalyptus tar (bio-oil) distilled within the boiling temperature ranges from $110{ }^{\circ} \mathrm{C}<\mathrm{T}^{\text {Boiling }}<300{ }^{\circ} \mathrm{C}$, using a $2000 \mathrm{~L}$ feed at $70 \mathrm{mmHg}$, without reflux. The reaction products consist of an aqueous phase $\left(\mathrm{T}^{\mathrm{Boiling}}<110^{\circ} \mathrm{C}\right)$, an organic phase (bio-oil) $\left(110{ }^{\circ} \mathrm{C}<\mathrm{T}^{\text {Boiling }<300 ~}{ }^{\circ} \mathrm{C}\right)$, and a pitch, showing an average bio-oil yield of 26.9 (wt.\%), an aqueous phase yield of 17.3 (wt.\%), a pitch yield of 50.9 (wt.\%), and 4.9 (wt.\%) losses. The GC-MS identified 0.63 (area.\%) acetic acid, 4.03 (area.\%) ketones, and 85.48 (area.\%) phenol derivatives, as well as 9.86 (area.\%) non-identified chemical compounds. In a secondary fractionation step, the bio-oil re-distilled at $340{ }^{\circ} \mathrm{C}$ and $10 \mathrm{mmHg}$, with reflux ration of 3:1 and 7:1, being the distillates fractionated into 95 samples. The GC-MS identified in all the samples only phenol derivatives (the distribution of phenol derivatives determined for all the samples and/or fractions was phenol, ethyl phenol, cresol, $o$-cresol, $p$-cresol, m-cresol, guaiacol, ethyl guaiacol, phenyl guaiacol, syringol, ethyl syringol, methyl syringol, and propyl syringol).

Adjaye and Bakhshi [23], investigated the distillation of maple wood bio-oil. Rapid thermal process (RTP) was carried out at $525^{\circ} \mathrm{C}$ and residence times were between 0.45 and 0.50 s. The yield of the bio-oil was 74 (wt.\%), containing 21 (wt.\%) $\mathrm{H}_{2} \mathrm{O}$. The bio-oil density and viscosity at $25{ }^{\circ} \mathrm{C}$ were $1.12 \mathrm{~g} / \mathrm{cm}^{3}$ and $9.0 \times 10^{-2} \mathrm{~Pa} \mathrm{~s}\left(80.36 \mathrm{~mm}^{2} / \mathrm{s}\right)$, respectively. The bio-oil distilled under a vacuum of $172 \mathrm{~Pa}$ and at 150,200 , and $250{ }^{\circ} \mathrm{C}$, heating rate of $40{ }^{\circ} \mathrm{C} / \mathrm{min}$, using a Buchi GKR-56 distillation unit. Vacuum distillation of bio-oils then yielded two fractions: a volatile (distillates) and a non-volatile fraction (bottoms), which were 54.6 (wt.\%) of distillate and $45.4 \%$ (wt.) residue at $150{ }^{\circ} \mathrm{C}, 63.4$ (wt.\%) distillate and $45.4 \%$ (wt. $\%$ ) residue at $200{ }^{\circ} \mathrm{C}$, and 54.6 (wt. $\%$ ) distillate and 45.4 (wt.\%) residue at $250{ }^{\circ} \mathrm{C}$. The GC-MS analysis of volatile (distillates) fraction identified carboxylic acids, esters, alcohols, aliphatic and aromatic hydrocarbons, aldehydes, ketones, amines, ethers, furans, phenols, with 6.0 (area.\%) hydrocarbons.

Boucher et al. [25], studied the distillation of softwood bark bio-oil produced by vacuum pyrolysis. The pyrolysis was carried out under vacuum in a pilot-scale reactor at $500{ }^{\circ} \mathrm{C}$ and $14 \mathrm{kPa}$, using $92 \mathrm{~kg}$ softwood bark residues with a particle diameter $\varnothing_{\text {Particle }}<14.0 \mathrm{~mm}$, in batch mode. The reaction products yielded 20 (wt.\%) bio-oil, 24 (wt.\%) aqueous phase, 35 (wt.\%) coke (solid phase), and 20 (wt.\%) gaseous phase. The aqueous phase composed by 84 (wt.\%) $\mathrm{H}_{2} \mathrm{O}$ and 16 (wt.\%) soluble/dissolved organic compounds. The density and kinematic viscosity of bio-oil were $1.066 \mathrm{~g} / \mathrm{cm}^{3}\left(20{ }^{\circ} \mathrm{C}\right)$ and $38.0 \mathrm{~mm}^{2} / \mathrm{s}\left(40^{\circ} \mathrm{C}\right)$, respectively, while the flash point was $>90^{\circ} \mathrm{C}$. The distillation was carried out in a $250 \mathrm{~mL}$ glass flask, coupled to a fractionation column, a condenser, and an electric heater, using $150 \mathrm{~g}$ of bio-oil at $140{ }^{\circ} \mathrm{C}, 1.0$ atmosphere. The yield of distillation (aqueous phase + organic phase) was 17.0 (wt.\%), while that of organic fraction, with initial boiling point $\left(\mathrm{T}^{\mathrm{IBP}}=140{ }^{\circ} \mathrm{C}\right)$, was 11.7 (wt.\%). At boiling temperature $\mathrm{T}^{\text {Boiling }}<100{ }^{\circ} \mathrm{C}$, the distillation curve exhibits the evaporation of $\mathrm{H}_{2} \mathrm{O}$ and low boiling point compounds, 
reaching a distillation yield of approximately 10.0 (wt.\%). After removal of $\mathrm{H}_{2} \mathrm{O}$, the slope of the distillation curve increases as molecules of high molecular weight evaporate.

Zheng and Wei [45] studied the distillation, under vacuum, of fast pyrolysis rice husk bio-oil at $80^{\circ} \mathrm{C}, 15 \mathrm{mmHg}$, using a distillation round bottom glass apparatus of $1000 \mathrm{~cm}^{3}$. The pyrolysis products include an aqueous phase $\left(\mathrm{H}_{2} \mathrm{O}\right.$, volatile organic acids, and oxygenate compounds), a bio-oil, and a residue. The yields of bio-oil, aqueous phase, and residue were 61 (wt.\%), 29 (wt.\%), and 10 (wt.\%), respectively. The density of biooil was $1.270 \mathrm{~g} / \mathrm{cm}^{3}$. The content of linear and aromatic carboxylic acids in fast bio-oil $\left(\mathrm{HCOOH}, \mathrm{CH}_{3} \mathrm{COOH}, \mathrm{C}_{6} \mathrm{H}_{4}(\mathrm{COOH})_{2}\right.$ ) decrease from 14.35 (wt.\%) to 1.01 (wt.\%) after distillation. The $\mathrm{pH}$ increased from 2.8 to 6.8 , proving that distillation was effective to de-acidify the bio-oil. In addition, distillation causes a deoxygenation of bio-oil, as the concentration of oxygenates decreased from 50.3 to 9.2 (wt.\%). In order to investigate the stability of bio-oil and distilled bio-oil, experiments were carried out to analyze variations on the kinematic viscosity $\left(20^{\circ} \mathrm{C}\right)$ within a period of 30 days. The results show that viscosity $\left(20^{\circ} \mathrm{C}\right)$ of bio-oil is almost constant $\left(\sim 210 \mathrm{~mm}^{2} \mathrm{~s}^{-1}\right)$ after distillation, and that of fast pyrolysis bio-oil increases from 130 to $240 \mathrm{~mm}^{2} \mathrm{~s}^{-1}$, showing that distillation produces a chemical stable distilled bio-oil.

Majhi et al. [50] investigated the distillation of jatropha curcas cake pyrolysis bio-oil. The pyrolysis was carried out in a fixed bed stainless steel tubular reactor $\left(\phi_{\mathrm{id}}=40 \mathrm{~mm}\right.$, $\mathrm{H}=240 \mathrm{~mm}, \mathrm{~V}_{\text {Reactor }}=301.6 \mathrm{~mL}$ ) in laboratory scale at $550{ }^{\circ} \mathrm{C}, 5^{\circ} \mathrm{C} / \mathrm{min}$ heating rate, $\mathrm{N}_{2}$ flow rate of $50 \mathrm{~cm}^{3} / \mathrm{min}$, using $250 \mathrm{~g}$ biomass with a particle diameter $\varnothing_{\text {Particle }} 0.5$ and $0.8 \mathrm{~mm}$. The distillation carried out in a $500 \mathrm{~mL}$ glass flask, coupled to a Hempel fractionating packed column and a condenser, using $300 \mathrm{~mL}$ of bio-oil. The temperature of gaseous phase was measured at the column outlet using a glass thermometer. The bio-oil was distilled within the boiling temperature ranges $\mathrm{T}^{\text {Boiling }}<140{ }^{\circ} \mathrm{C}, 140{ }^{\circ} \mathrm{C}<\mathrm{T}^{\text {Boiling }}<250{ }^{\circ} \mathrm{C}$, and $\mathrm{T}^{\text {Boiling }}>250^{\circ} \mathrm{C}$. The bio-oil density, kinematic viscosity, and flash point were $1.100 \mathrm{~g} / \mathrm{cm}^{3}$, $3.96 \mathrm{~mm}^{2} / \mathrm{s}$, and $180^{\circ} \mathrm{C}$, respectively, containing 15.4 (wt.\%) $\mathrm{H}_{2} \mathrm{O}$. The bio-oil distilled fraction within the boiling temperature range $T_{\text {Boiling }}<140{ }^{\circ} \mathrm{C}$ had a density of $0.8735 \mathrm{~g} / \mathrm{cm}^{3}$, kinematic viscosity of $2.35 \mathrm{~mm}^{2} / \mathrm{s}$, and flash point of $41^{\circ} \mathrm{C}$, containing less than 0.05 (wt.\%) $\mathrm{H}_{2} \mathrm{O}$, and acidity less than $0.05 \mathrm{mg} \mathrm{KOH} / \mathrm{g}$. FT-IR analysis identified the presence of alkenes and mono and polycyclic substituted aromatic groups, confirming that $\mathrm{T}^{\text {Boiling }}<140{ }^{\circ} \mathrm{C}$ distillation fraction contains no polar compounds. In addition, GC analysis identified the presence of non-polar compounds including hexane, methyl cyclopentane, 3,3-dimethyl cyclopentane, 3-methylhexane, methyl cyclohexane, and toluene.

Zhang et al. [51] studied the distillation of fast co-pyrolysis of rice Rusk and ADR (Atmospheric Distillation Residue). The fast pyrolysis was carried out in a downdraft fixedbed reactor, under $\mathrm{N}_{2}$ atmosphere at flow rate of $0.16 \mathrm{~L} / \mathrm{min}$, reaction time between $1-2 \mathrm{~s}$, at $450{ }^{\circ} \mathrm{C}$, using $5.0 \mathrm{~g}$ of dried rice Rusk with a particle diameter $\varnothing_{\text {Particle }}<88.0 \mu \mathrm{m}$. The copyrolysis was carried out by mixing dried rice Rusk and ADR powder $\left(\varnothing_{\text {Particle }}<300.0 \mathrm{~mm}\right)$, and the ADR powder content was set at 15, 20, 25, 30 and 35 (wt.\%) of feed. The distillation was carried out in a round-bottom flask placed, using an oil bath heating system, under vigorous magnetic stirring, at $240{ }^{\circ} \mathrm{C}$ and 1.0 atmosphere. The distillation products include the distilled bio-oil, a residual solid phase (ADR), non-condensable gases, and residual bio-oil. The yields of distillation fractions (FI, FII, FIII, FIV, FV, and FVI) increased with temperature, varying between 33 and 51.86 (wt.\%), within the interval $145{ }^{\circ} \mathrm{C}<\mathrm{T}^{\mathrm{Boiling}}<240^{\circ} \mathrm{C}$. The content of carboxylic acid (acetic acid, propionic acid, and $n$-butyric acid) decreased in distilled fractions FI [2.74 (wt.\%)], FII [1.026 (wt.\%)], and FIII [0.529 (wt.\%)], increased in distilled fractions FIV [0.627 (wt.\%)] and FV [1.092 (wt.\%)], and decreased again in fraction FVI [0.475 (wt.\%)], the same behavior observed for the content of furfural and phenols derivatives (phenol, o-cresol, p-cresol, and guaiacol). In addition, the $\mathrm{H}_{2} \mathrm{O}$ content present in the distilled fraction FVI was 37.13 (wt.\%), higher than that of raw bio-oil, equal to 30.3 (wt.\%), showing that dehydration reactions occurred. For the distillation of fast co-pyrolysis bio-oils obtained by mixing rice Rusk and ADR, one can observe that yields of bio-oil remain almost constant ( 46-47) (wt.\%), while those of char increase from 37 
to 41 (wt.\%) and those of non-condensable gases decrease from 18 to 14 (wt.\%) with increasing ADR content in feedstock. Finally, experimental results based on the elemental analysis and chemical identification by GC-MS show that distillation of bio-oils can be considered a reactive distillation process, as the solid phase (ADR) contains substance of high molecular weight and carbon chain length, not detected and/or identified in the raw bio-oil by GC-MS.

Capunitan and Capareda [52] investigated the distillation of corn Stover bio-oil under atmospheric and vacuum conditions ( $0.5 \mathrm{bar})$. The bio-oil produced by pyrolysis of corn Stover using a high-pressure reactor at $400{ }^{\circ} \mathrm{C}$, in batch mode, contains 20.3 (wt.\%) $\mathrm{H}_{2} \mathrm{O}$. The aqueous phase acidity was $24.6 \mathrm{mg} \mathrm{KOH} / \mathrm{g}$ oil. The distillation set-up consisted of distillation flasks, a fractionating column, a condenser, and collecting flasks, using $10 \mathrm{~g}$ bio-oil. For the distillation in atmospheric conditions, bio-oil was distilled within the boiling temperature ranges $\mathrm{T}^{\text {Boiling }}<100{ }^{\circ} \mathrm{C}, 100{ }^{\circ} \mathrm{C}<\mathrm{T}^{\text {Boiling }}<180{ }^{\circ} \mathrm{C}$, and $180{ }^{\circ} \mathrm{C}<\mathrm{T}^{\text {Boiling }}<250{ }^{\circ} \mathrm{C}$, while that under vacuum was within the boiling temperature ranges $\mathrm{T}^{\text {Boiling }}<80^{\circ} \mathrm{C}, 80^{\circ} \mathrm{C}<\mathrm{T}^{\text {Boiling }}<160^{\circ} \mathrm{C}$, and $160^{\circ} \mathrm{C}<\mathrm{T}^{\text {Boiling }}<230^{\circ} \mathrm{C}$. Atmospheric distillation of bio-oil yields 15.0 (wt.\%) of an organic phase and 18.7 (wt.\%) of an $\mathrm{H}_{2} \mathrm{O}$ phase at $100{ }^{\circ} \mathrm{C}, 4.7$ (wt.\%) of an organic phase between $100{ }^{\circ} \mathrm{C}<\mathrm{T}^{\text {Boiling }}<180{ }^{\circ} \mathrm{C}$, and 45.3 (wt. \%) of an organic phase between $180{ }^{\circ} \mathrm{C}<\mathrm{T}^{\text {Boiling }}<250{ }^{\circ} \mathrm{C}$. The vacuum distillation yields 10.3 (wt.\%) of an organic phase and 16.2 (wt.\%) of a $\mathrm{H}_{2} \mathrm{O}$ phase at $80{ }^{\circ} \mathrm{C}, 5.9$ (wt.\%) of an organic phase between $80^{\circ} \mathrm{C}<\mathrm{T}^{\text {Boiling }}<160{ }^{\circ} \mathrm{C}$, and 40.9 (wt.\%) of an organic phase between $160{ }^{\circ} \mathrm{C}<\mathrm{T}^{\text {Boiling }}<230^{\circ} \mathrm{C}$. The acid values of distillation fractions under atmospheric conditions were 4.1,15.1, and $7.4 \mathrm{mg} \mathrm{KOH} / \mathrm{g}$ oil, while those under vacuum were 3.0, 13.9, and $5.0 \mathrm{mg} \mathrm{KOH} / \mathrm{g}$ oil. Chemical functions characteristic of hydrocarbons (alkanes, aromatics) and oxygenates (aldehydes, alcohols, and phenols) were identified by FT-IR. The GC analysis identified in the distillation fraction obtained under atmospheric and vacuum condition, the presence of paraffin's, naphthenics, aromatics, oxygenates, furans, and phenols, being the content of hydrocarbons 23.1, 17.1, and 7.1 (area.\%) under atmospheric conditions, and 22.2, 18.4, and 7.4 (area.\%) under vacuum conditions.

Elkasabi et al. [57] studied the fractional distillation of tail-gas reactive pyrolysis biooil of horse manure (TGPHM), switch grass (TGPSG), and eucalyptus (TGPE), and the fast pyrolysis bio-oil of horse manure (BHM), switch grass (BSG), and eucalyptus (BE) to fractionate and enrich chemical compounds. TGPHM, TGPSG, and TGPE were produced by pyrolysis of tail-gas with recycle rates of 70,70, and 50 (vol.\%), respectively. A vacuumjacketed distillation apparatus of $100 \mathrm{~mL}$ (Vigreux), operating in batch mode, coupled to a Liebig condenser, was used to carry out the distillation experiments under vacuum and $1.0 \mathrm{~atm}$. The distillation apparatus was connected to a $100 \mathrm{~mL}$ round-bottomed glass flask, inserted inside a heating mantle with digital temperature control. The vapor temperature was measured at the column top outer joint. The reduced pressure (vacuum) distillation was applied when the bottom flask temperature reached $350{ }^{\circ} \mathrm{C}$. The distillation yields of tail-gas reactive pyrolysis bio-oils TGPHM, TGPSG, and TGPE were 56.3, 55.8, and 54.1 (wt.\%), respectively. The distillation yields of fast pyrolysis bio-oils BHM, BSG, and BE were 24.2, 33.1, and 38.9 (wt.\%), respectively. The acid values of all distillation fractions of TGPHM, TGPSG, and TGPE decrease with increasing vapor temperature. The acid values of lighter distillation fractions are very high, compared to the initial acid value of TGPSG and TGPE, showing that fractional distillation was not effective in decreasing the acidity of tail-gas reactive pyrolysis bio-oil with initial high acid values.

Huang et al. [70], investigated the fluidized bed pyrolysis with in-line distillation of rice Rusk under atmospheric conditions. The bio-oil was produced by pyrolysis of rice Rusk using a fluidized bed pyrolyzer $\left(\phi_{\mathrm{id}}=50 \mathrm{~mm}, \mathrm{H}=500 \mathrm{~mm}, \mathrm{~V}_{\text {Reactor }}=981.7 \mathrm{~mL}\right)$ at 490 and $590{ }^{\circ} \mathrm{C}, \mathrm{N}_{2}$ flow rate of $10.0 \mathrm{~mL} / \mathrm{min}$, gas fluidization velocity of $0.36,0.46$, and $0.56 \mathrm{~m} / \mathrm{s}$, and feed flow rate of $10.0 \mathrm{~g} / \mathrm{min}$, with a particle diameter $1.68 \mathrm{~mm}<\varnothing_{\text {Particle }}<3.36 \mathrm{~mm}$. The distillation column contains 04 stages, $4.75 \mathrm{~cm}$ internal diameter, and 43.0 height, connected to the fluidized bed pyrolyzer. The distillation fractions at the bottom stage were collected at $136{ }^{\circ} \mathrm{C}$. In addition, 02 condenser at $20^{\circ} \mathrm{C}$ and $0{ }^{\circ} \mathrm{C}$ was used to complete 
the fractionation of bio-oil distillation. For the pyrolysis experiments carried out at $590{ }^{\circ} \mathrm{C}$ and $0.36 \mathrm{~m} / \mathrm{s}$, the composition of distillation fraction collected in the first stage (bottom) at $136{ }^{\circ} \mathrm{C}$ contained 63.32 (area.\%) phenols, 1.47 (area.\%) furans, and 4.87\% (area.\%) hydrocarbons. Inside the condenser at $20{ }^{\circ} \mathrm{C}$, the composition of condensates contained 63.34 (area.\%) acetic acid, 14.85 (area.\%) phenols, 8.04 (area.\%) ketones, and 4.33 (area.\%) furfural, and inside the condenser at $0{ }^{\circ} \mathrm{C}$, the composition of condensates contained 28.66 (area.\%) acetic acid, 34.48 (area.\%) phenols, 3.31 (area.\%) ketones, 4.84 (area.\%) furans, and 2.73 (area.\%) hydrocarbons.

Huang et al. [70,72], investigated the fluidized bed pyrolysis with in-line distillation of rice Rusk under atmospheric conditions. The bio-oil was produced by pyrolysis of rice Rusk using a fluidized bed pyrolyzer $\left(\phi_{\mathrm{id}}=50 \mathrm{~mm}, \mathrm{H}=500 \mathrm{~mm}, \mathrm{~V}_{\text {Reactor }}=981.7 \mathrm{~mL}\right)$ at 500 and $600{ }^{\circ} \mathrm{C}, \mathrm{N}_{2}$ flow rate of $10.0 \mathrm{~mL} / \mathrm{min}$, gas fluidization velocity of $0.255,0.340$, and $0.425 \mathrm{~m} / \mathrm{s}$, and feed flow rates of 10.0 and $20.0 \mathrm{~g} / \mathrm{min}$, particle diameter $1.68 \mathrm{~mm}<\varnothing_{\text {Particle }}<3.36 \mathrm{~mm}$. The distillation column contains 04 stages, $4.75 \mathrm{~cm}$ internal diameter, and 43.0 height, and was connected to the fluidized bed pyrolyzer. The distillation fractions were collected in the first (bottom) stage at $120^{\circ} \mathrm{C}$ and the third stage at $80^{\circ} \mathrm{C}$. In addition, 02 condensers at $20^{\circ} \mathrm{C}$ and $0{ }^{\circ} \mathrm{C}$ were used to complete the fractionation of bio-oil distillation. For the pyrolysis experiment carried out at $500{ }^{\circ} \mathrm{C}, 10.0 \mathrm{~g} / \mathrm{min}$, and $0.340 \mathrm{~m} / \mathrm{s}$, the composition of distillation fraction collected in the first stage (bottom) at $120{ }^{\circ} \mathrm{C}$ contained 34.12 (area.\%) phenols, 7.59 (area.\%) ketones, 0.56 (area.\%) anhydride acetic, and 3.41 (area.\%) hydrocarbons. The distillation fraction collected in the third stage at $80{ }^{\circ} \mathrm{C}$ contained $40.96 \%$ (area. $\%$ ) phenols, $9.78 \%$ (area.) ketones, $0.78 \%$ (area.\%) anhydride acetic, and 3.87\% (area.\%) hydrocarbons. In addition, 02 condensers at $20^{\circ} \mathrm{C}$ and $0{ }^{\circ} \mathrm{C}$ were used to complete the fractionation of bio-oil distillation, which was the composition of condensates inside the condenser at $20^{\circ} \mathrm{C}$, composed by 35.59 (area.\%) acetic acid, 10.81 (area.\%) phenols, 15.91 (area.\%) ketones, 6.35 (area.\%) furfural, 2.19 (area.\%) anhydride acetic, and 4.69 (area.\%) hydrocarbons. Inside the condenser at $0{ }^{\circ} \mathrm{C}$, the condensates were composed by 10.17 (area.\%) acetic acid, 27.17 (area.\%) phenols, 8.03 (area.\%) ketones, 8.28 (area.\%) furfural, 1.57 (area.\%) anhydride acetic, and 4.12 (area.\%) hydrocarbons.

The work investigates systematically the influence of production scales (laboratory, bench, and pilot) by pyrolysis of pretreated (drying, milling, and sieving) Açaí seeds at $450{ }^{\circ} \mathrm{C}$ and 1.0 atmosphere, on the yields of reaction products (bio-oil, aqueous phase, coke, and gas) and the acid value of bio-oils. The bio-oil obtained in the pilot scale was submitted/subjected to fractional distillation using a laboratory-scale column (Vigreux) of $30 \mathrm{~cm}$ to study the feasibility of producing fuel-like fractions (gasoline, light-kerosene, and kerosene), determine the chemical composition of bio-oils and distillation fractions, as well as to perform the physical-chemistry (density, kinematic viscosity, acid value, and refractive index) characterization of distillation fractions.

\section{Materials and Methods}

\subsection{Methodology}

The process flow sheet shown in Figure 1 summarizes the applied methodology, described in a logical sequence of ideas, chemical methods, and procedure to produce fuel-like fractions (gasoline, light kerosene, and kerosene) by fractional distillation of biooil produced by thermal degradation (pyrolysis) of Açaí seeds at $450{ }^{\circ} \mathrm{C}$ and $1.0 \mathrm{~atm}$, in laboratory, bench, and pilot scales. Initially, the Açaí seeds are collected. Afterwards, they are subjected to pretreatments of drying to diminish moisture content, followed by milling and sieving. The pyrolysis carry out in different production scales (laboratory, bench, and pilot) to investigate the influence on reaction products (coke, bio-oil, $\mathrm{H}_{2} \mathrm{O}$, and gas), particularly the bio-oil, as well as on the acid value of bio-oil. The bio-oil was produced in pilot scale, submitted to fractional distillation to produce gasoline, light kerosene, and kerosene-like fractions. The physical-chemistry properties and chemical composition of distillation fractions were determined. 


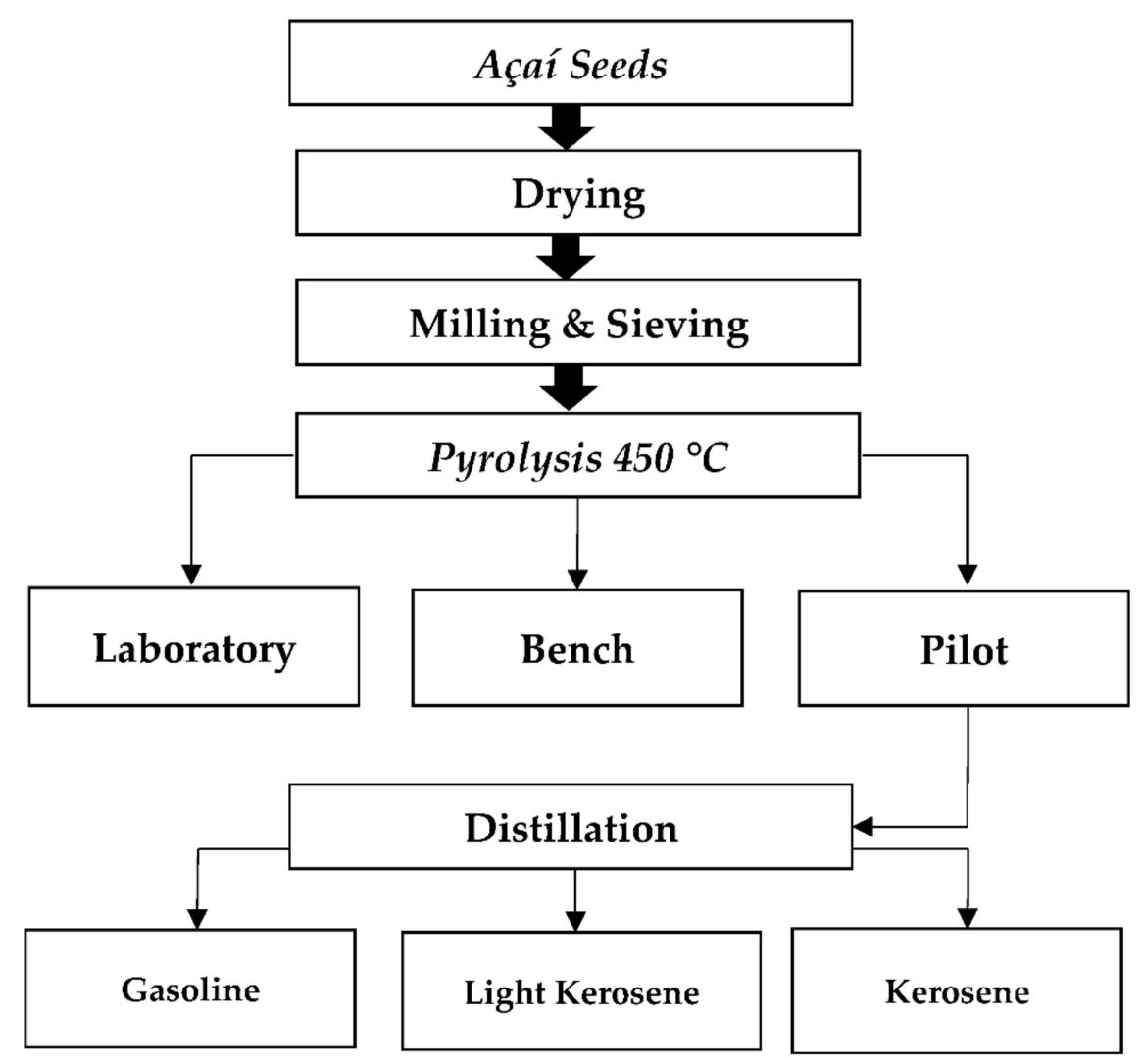

Figure 1. Process flow sheet by the production of fuel-like fractions (gasoline, light kerosene, and kerosene) obtained by fractional distillation of bio-oil obtained in laboratory, bench, and pilot scales.

\subsection{Materials}

By the processing of Açaí fruits in nature with warm water to produce a purplecolored juice or a paste [3,4], a byproduct, the Açai seeds, is generated [3,7,8]. The seeds of Açaí were obtained in a small store of Açaí commercialization, located in the City of Belém-Pará-Brazil [73].

\subsection{Pre-Treatment of Açaí Seeds in Nature}

The seeds had a high moisture content, not only because the pulping process uses water to extract the Açaí juice, but also due to its incorrect disposal, exposed to the environment. The high moisture content of raw materials favors the generation of undesirable products. In this sense, it was necessary to dry the seeds. Next, $750 \mathrm{~kg}$ of Açaí seeds weighed and separated into five loads/charges of $150 \mathrm{~kg}$. Afterwards, the charges were subjected to the drying process in a pilot thermal oven with air recirculation and analog temperature control (FABBE. Ltda, São Paulo-Brazil, Model: 170), at $110{ }^{\circ} \mathrm{C}$ for $24 \mathrm{~h}$. The dried seeds were grounded using a pilot knife mill (TRAPP, Model: TRF 600). Bottom sieves with $0.8 \mathrm{~mm}$ and $5.0 \mathrm{~mm}$ opening diameters were fixed at the cutting mill exit. Two charges with $50.0 \mathrm{~kg}$ of dried seeds were sieved, the first using a bottom sieve of $0.80 \mathrm{~mm}$, while the second used a bottom sieve of $5.0 \mathrm{~mm}$. Afterwards, the dried and grounded seeds were sieved using a $0.6 \mathrm{~mm}$ sieve to remove the excess fibers from Açaí seeds. Figure 2 shows the material after the drying, milling and sieving process of Açaí seeds to carry out the pyrolysis experiments [Seeds + Fibers (a); Comminuted Seeds + Fibers (b); Fibers (c); and Comminuted Seeds (d)]. The pretreatments of drying, milling, and sieving increases the biomass contact-surface for carbonization and the uniformity (particle size distribution) of the raw material. The pyrolysis experiments were carried out with comminuted seeds, as shown in Figure 2d. 


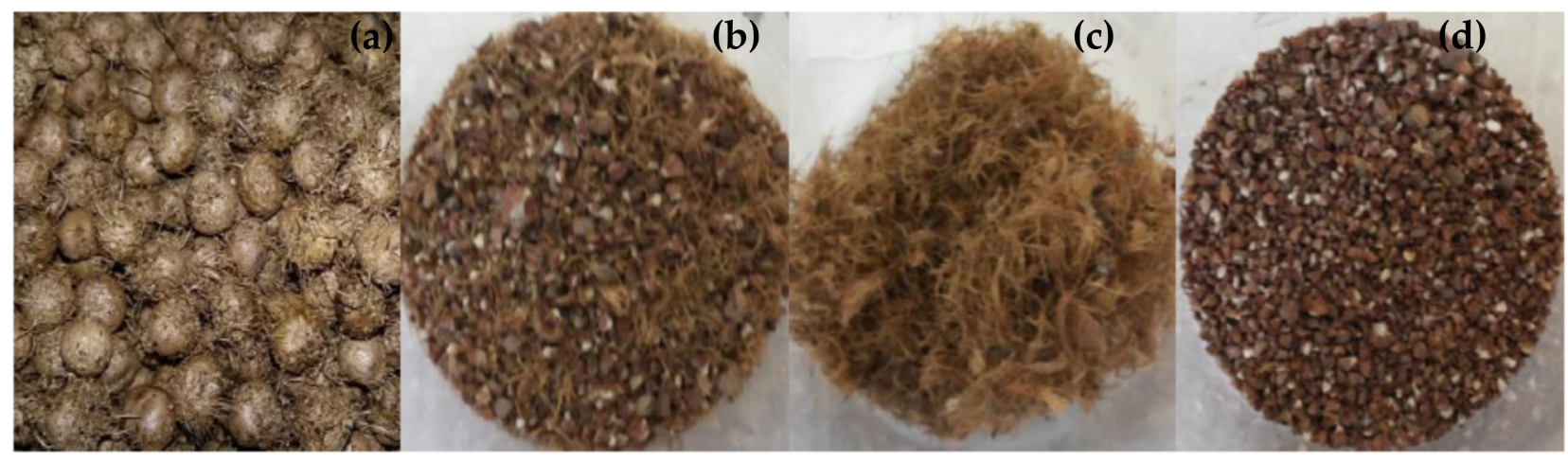

Figure 2. Material after drying, milling, and sieving process of Açaí seeds [Seeds + Fibers (a); Comminuted Seeds + Fibers (b); Fibers (c); and Comminuted Seeds (d)].

\subsection{Centesimal Characterization of Açaí Seeds}

The dried seeds in nature were physico-chemically characterized for moisture, volatile matter, ash, and fixed carbon according to official methods ASTM D 3173-87, ASTM D 3175-04, ASTM D 3174-04, and ASTM D3172-89 [73]. In a previous study [74], the dried Açaí seeds were physico-chemically characterized for lipids, proteins, fibers, cellulose, hemicellulose, and insoluble lignin according to official methods [73-76].

\subsection{Experimental Apparatus and Procedures}

\subsubsection{Pyrolysis Units}

The experiments were carried out in laboratory, bench, and pilot scales at $450{ }^{\circ} \mathrm{C}$ and 1.0 atmosphere, and all the apparatuses in laboratory, bench, and pilot scales are described in detail elsewhere [77].

The pyrolysis unit in laboratory scale consists of a cylindrical borosilicate glass reactor of $200 \mathrm{~cm}^{3}$. The reactor was inserted in a cylindrical oven with a ceramic resistance of $800 \mathrm{~W}$, with a digital temperature and heating rate control system (THERMA, São PauloBrazil, Model: TH90DP202-000), and the temperature was measured with the aid of a K-type thermocouple sensor (Ecil, São Paulo-Brazil, Model: QK. 2). A borosilicate glass Liebig condenser was connected to the reactor exit using a $Y$ shaped connection and used to liquefy the gaseous phase, with cooling $\mathrm{H}_{2} \mathrm{O}$ supplied by a thermostatic recirculation bath (VWR) with digital temperature control. The liquid phase products were collected in a $50 \mathrm{~mL}$ borosilicate glass flask. The non-condensable gaseous products $\left(\mathrm{CH}_{4}, \mathrm{CH}_{3}\right.$ $\mathrm{CH}_{3}, \mathrm{CH}_{3}-\mathrm{CH}_{2}-\mathrm{CH}_{3}, \mathrm{O}_{2}, \mathrm{CO}, \mathrm{CO}_{2}, \mathrm{H}_{2}$, etc.) flow through an opening in the $90^{\circ}$ curve, coupled between the Liebig condenser and the collection flask, to the flare system. Figure 3 illustrates the pyrolysis unit in laboratory scale.

The bench pyrolysis unit, mounted on a movable metallic structure, consists of a cylindrical Reactor (R-1) constructed by AISI 304 Stainless steel of 2.0 L. The experimental apparatus has a control unit with a PLC (Programmable Logic Controller), making it possible to control the reactor temperature, heating rate, and the mechanical stirrer angular velocity. The reactor operating temperature is programmed using a temperature controller (NOVUS, Model: N1100), coupled to a K-type thermocouple inside the reactor (R-1). The reactor connected to a stainless steel double pipe condenser ( $\mathrm{DN} \frac{1}{2}$ ") with a heat exchange area of $0.05 \mathrm{~m}^{2}$, coupled to a thermostatic recirculation bath with digital temperature control, using $\mathrm{H}_{2} \mathrm{O}$ as cooling fluid. The liquefied products were withdrawn using a $2.0 \mathrm{~L}$ stainless steel collection vessel (C-01). The non-condensable gaseous products flow through an escape valve located between the condenser and the collection vessel, and burned in the flare system. Figure 4 illustrates the pyrolysis unit in bench scale. 


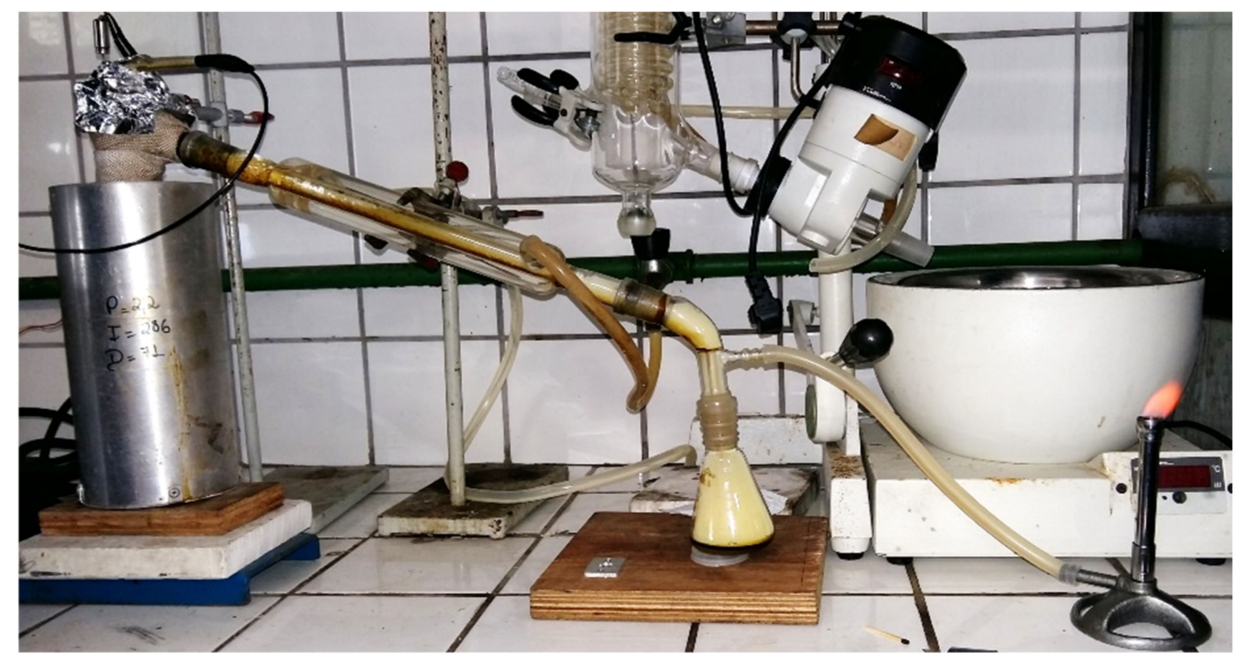

Figure 3. View of the pyrolysis unit in laboratory scale.

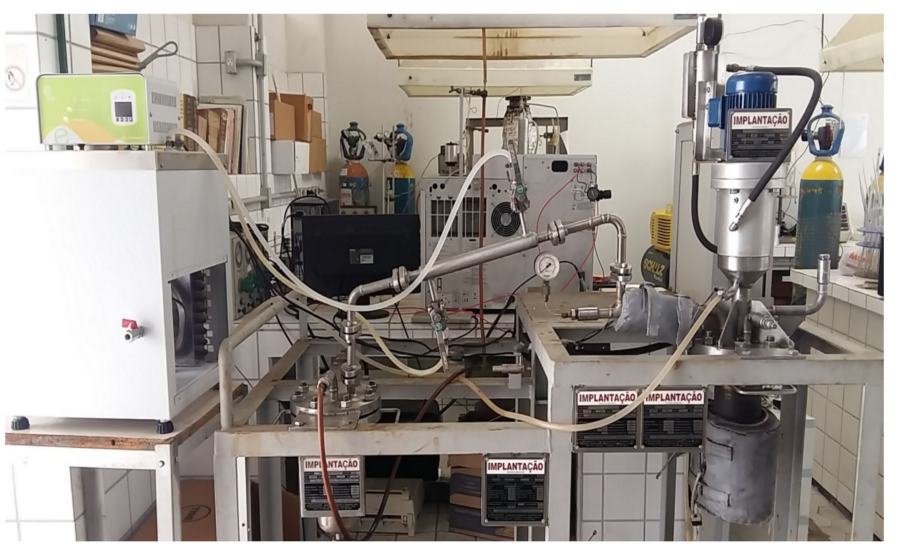

Figure 4. View of the pyrolysis unit in bench scale.

The pilot unit is described/presented in detail elsewhere [77]. The unit is composed of seven operational sections (feed/pumping section, pre-heating section, reacting section, cooling section, condensation section, separation \& collection, and burning of noncondensable gases, instrumentation and control section). The reacting section consists of the jacketed stainless steel reactor with mechanical stirring system (R-01) of $145 \mathrm{~L}$, operating pressure 1.0 atmosphere, and operating temperature $500{ }^{\circ} \mathrm{C}$. LPG supplies the thermal energy to the reactor (R-01), with the aid of a digital controlled burning system (HOLLAMAQ-MB-20/AB-R, SERIES 05-10), inlet pressure of 0.0-45.0 mbar and energy capacity of 5.000-30,000 Kcal/h, with the mixture LPG-air burning within the annular space concentric to R-01. Figure 5 illustrates the pyrolysis unit in pilot scale. The cooling section consists of 03 polyethylene tanks of $500 \mathrm{~L}$, with $\mathrm{H}_{2} \mathrm{O}$ at $25^{\circ} \mathrm{C}$, connected to the condenser in a closed loop. $\mathrm{H}_{2} \mathrm{O}$ flows continuously using 01 (one) centrifugal pump (DANCOR, CHS-17) of 1.0 Hp. The condensation section has a multi-tube stainless steel heat exchanger (C-01) of $1.30 \mathrm{~m}^{2}$, maximum mass flow of condensing gases of $25 \mathrm{~kg} / \mathrm{h}, \mathrm{H}_{2} \mathrm{O}$ flow rate at $25^{\circ} \mathrm{C}$ of $4.5 \mathrm{~m}^{3} / \mathrm{h}$, maximum temperature and operating temperatures of 100 and $50{ }^{\circ} \mathrm{C}$, pipe side design pressure and test pressure 1.0 atmosphere, operating in countercurrent mode. The separation \& collection, and burning of non-condensable gases contains a stainless steel collection vessel (VC-02) of $30.0 \mathrm{~L}$, operating pressure 1.0 atmosphere. The non-condensable gases exhausted using piping lines of $25 \mathrm{~mm}$ and gate valves at the top of VC-02 collection vessel. The non-condensable gases burned in the flare system. 


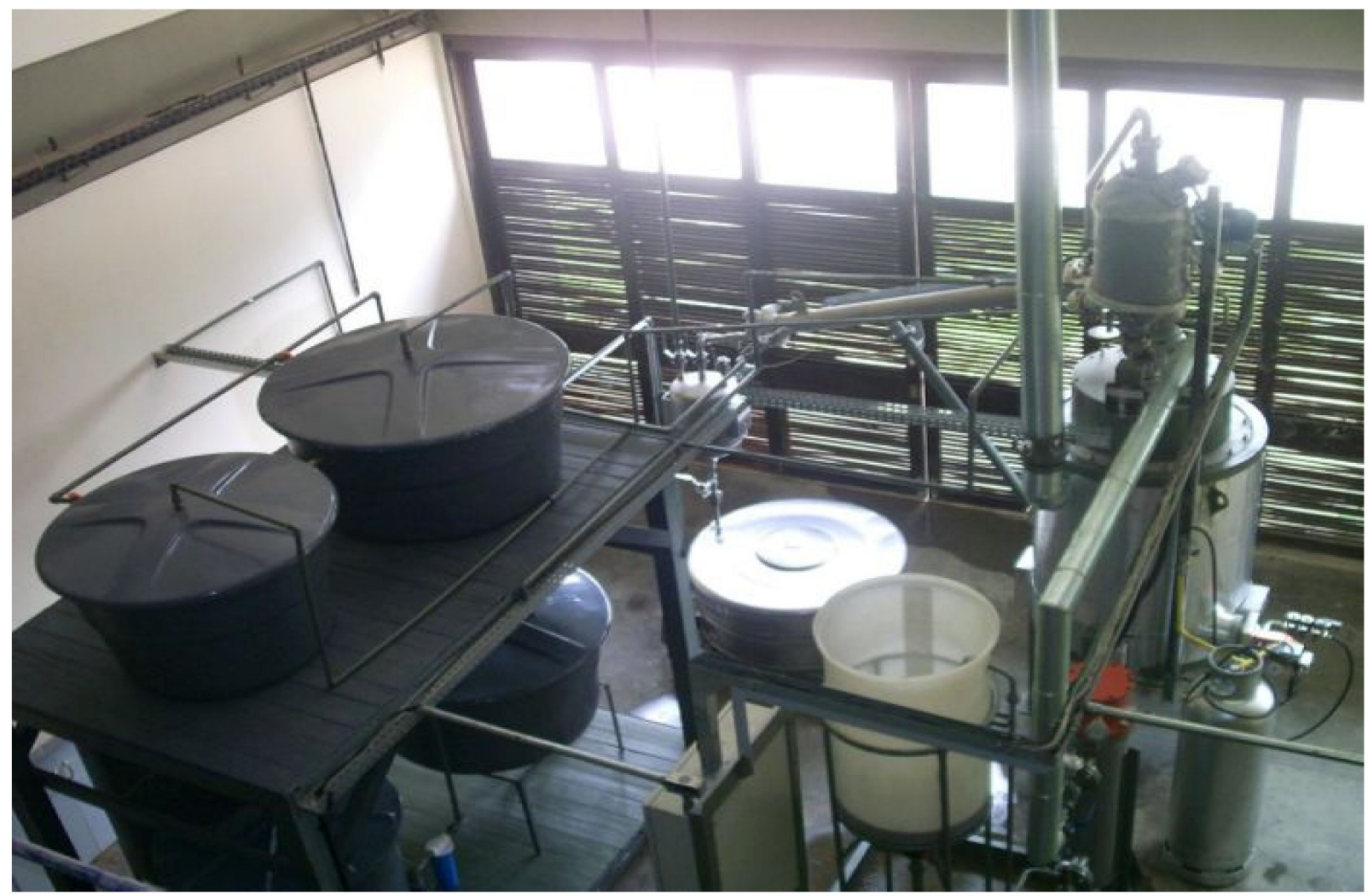

Figure 5. View of the pyrolysis unit in pilot scale.

\subsubsection{Experimental Procedures}

The pyrolysis of dried Açaí seeds carried out in laboratory, bench, and pilot scale. Pyrolysis in laboratory scale performed using approximately $50.0 \mathrm{~g}$ seeds, weighed on a semi-analytical balance (QUIMIS, São Paulo-Brazil, Model: Q-500L210C), placed inside the reactor. Afterwards, the reactor inserted in the jacketed cylindrical furnace. The control system programmed the reaction time, the heating rate, and the process temperature. The heating rate was set equal to $10^{\circ} \mathrm{C} / \mathrm{min}$. The reactor was maintained for $10 \mathrm{~min}$ at $450{ }^{\circ} \mathrm{C}$ after reaching the set point temperature. The liquid product subjected to filtration to separate the aqueous/bio-oil phases and compute the yields of bio-oil and aqueous phases. The coke weighed and the mass of gaseous phase computed by difference. This separation carried out with aid of a glass funnel and a porous filter medium (Qualitative Filter Paper 24.0 Ø; J. PROLAB). Pyrolysis in bench scale performed using approximately $900.0 \mathrm{~g}$ seeds, weighed on a semi-analytical balance (QUIMIS, São Paulo-Brazil, Model: Q-500L210C), placed inside the reactor. The control unit programmed the reaction time, the heating rate, and the process temperature. The heating rate was set equal to $10{ }^{\circ} \mathrm{C} / \mathrm{min}$. This separation carried out with aid of a glass funnel and a porous filter medium (Qualitative Filter Paper 24.0 Ø; J. PROLAB). The liquid product subjected to filtration to separate the aqueous/bio-oil phases and compute the yields of bio-oil and aqueous phases. The solid phase weighed and the mass of gaseous phase computed by difference. Pyrolysis in pilot scale is performed using approximately $30.0 \mathrm{~kg}$ seeds, weighed with the aid of a digital scale (DIGI-TRON, Curitiba-Brazil, Class III). Then, the reactor fed manually by the upper inlet. Afterwards, LPG gas cylinder weighed in order to compute the fuel consumption. The control unit programmed the process temperature. The rector temperature monitored every $10 \mathrm{~min}$ to register the formation of liquid and gaseous products. As the temperature rises, the gaseous reaction products condensed inside the collection vessel (VC-02). The non-condensable gases burned in the flare system. The reaction time computed from the moment the reactor reached the operating temperature (set point). The liquid (aqueous 
fraction + bio-oil) and the solid products weighed to compute the process yields. The liquid (aqueous fraction + bio-oil subjected to filtration using a glass funnel and a porous filter medium (Qualitative Filter Paper 24.0 Ø; J. PROLAB).

\subsubsection{Distillation Unit}

The fractional distillation of bio-oil was performed using an experimental apparatus similar to those described in the literature [73,77-79]. The distillation apparatus, illustrated in Figure 6, is described in detail by Ferreira et al. [79]. The distillation fractions were subjected to the pretreatment of decantation to separate the aqueous and organic phases, and the organic phase submitted to filtration to remove small solid particles.

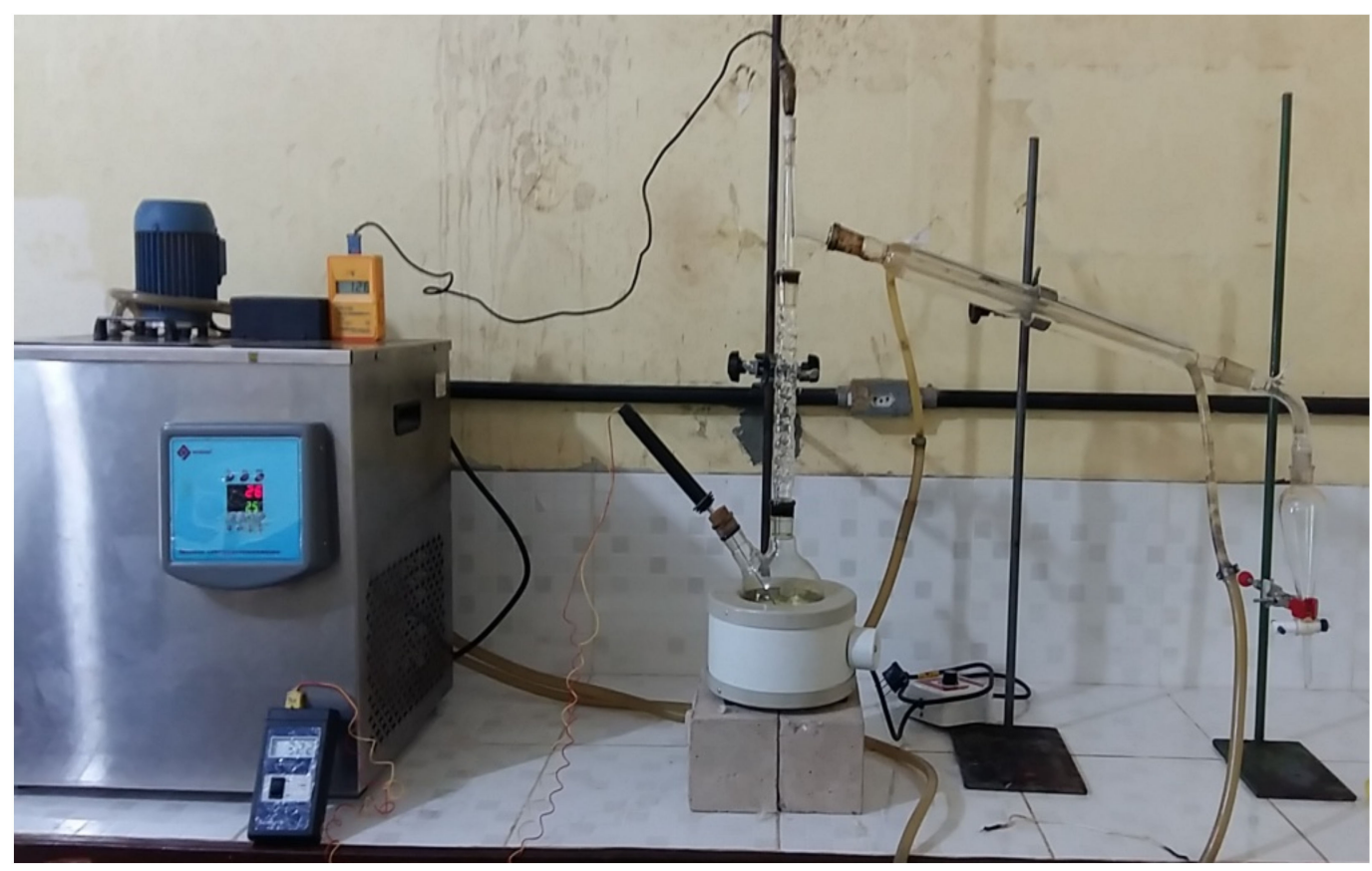

Figure 6. View of distillation column (Vigreux).

2.6. Physical-Chemistry Analysis and Chemical Composition of Bio-Oils and Distillation Fractions 2.6.1. Physical-Chemistry Analysis of Distillation Fractions

The bio-oils and the distillation fractions were (gasoline, light kerosene, and kerosene) physical-chemistry analyzed for acid value, density at $25^{\circ} \mathrm{C}$, kinematic viscosity at $40^{\circ} \mathrm{C}$, and refractive index according to official methods, as described elsewhere [73,77-79]. The analysis of chemical functions (carboxylic acids, aliphatic and aromatic hydrocarbons, ketones, phenols, aldehydes, furans, esters, ethers, etc.) present in distillation fractions determined by FT-IR [73,77-80].

\subsubsection{Chemical Composition of Bio-Oils and Distillation Fractions}

The composition bio-oils and distillation fractions determined by CG-MS and the equipment and operational procedures described in details elsewhere [73]. The identification of compounds in bio-oils and distillation fractions performed by CG-MS, and the equipment details described in the literature [73]. The GC-MS operating conditions illustrated in Table 1. The intensity, retention time, and compound identification were analyzed according to the NIST mass spectra library. The concentration of all oxygenates and hydrocarbons in each sample was expressed in each area, as no internal standard was injected to compare the peak areas. 
Table 1. The GC-MS operating conditions.

\begin{tabular}{|c|c|c|c|c|}
\hline \multirow{4}{*}{ Injetor } & \multirow{4}{*}{ Injection } & \multirow{2}{*}{$\mathrm{T}\left({ }^{\circ} \mathrm{C}\right)$} & Flow Rate (mL/min) & Split \\
\hline & & & 6.0 & $1: 50$ \\
\hline & & \multirow{2}{*}{250} & Heating Rate $\left({ }^{\circ} \mathrm{C} / \mathrm{min}\right)$ & Volume $(\mu \mathrm{L})$ \\
\hline & & & 10 & 1.0 \\
\hline \multirow{5}{*}{ Oven } & Heating Rate $\left({ }^{\circ} \mathrm{C} / \mathrm{min}\right)$ & \multicolumn{2}{|c|}{$\mathrm{T}\left({ }^{\circ} \mathrm{C}\right)$} & Residence Time (min) \\
\hline & - & \multirow{2}{*}{\multicolumn{2}{|c|}{60}} & 1 \\
\hline & 5 & & & 2 \\
\hline & 20 & \multicolumn{2}{|c|}{230} & 10 \\
\hline & 10 & \multicolumn{2}{|c|}{280} & 39 \\
\hline \multirow{2}{*}{ Detector (MS) } & $\mathrm{T}\left({ }^{\circ} \mathrm{C}\right)$ & Carrier Gas & \multirow{2}{*}{$\begin{array}{c}\text { Flow Rate }(\mathrm{mL} / \mathrm{min}) \\
30.0\end{array}$} & $\mathrm{~T}\left({ }^{\circ} \mathrm{C}\right)$ Quadrupole \\
\hline & 230 & $\mathrm{He}$ & & 150 \\
\hline
\end{tabular}

\section{Results}

\subsection{Pre-Treatments and Centesimal Characterization of Açaí Seeds}

The yields of drying, comminution and sieving pre-treatments were 58.92, 94.34, and 84.36 (wt.\%), showing a water content of 41.08 (wt.\%). The global yield of drying, comminution and sieving pre-treatments was 46.84 (wt.\%). The moisture, volatile matter, ash, and fixed carbon content of Açaí seeds, determined according to official methods [73], were $12.45,85.98,0.42$, and 13.60 (wt.\%).

\subsection{Pyrolysis of Açaí Seeds}

\subsubsection{Material Balances, Operating Conditions, and Yields of Reaction Products}

Table 2 summarizes the material balance, process conditions, and yields of reaction products by pyrolysis of Açaí seeds at $450{ }^{\circ} \mathrm{C}$ and 1.0 atmosphere, in laboratory, bench, and pilot scales. Figure 7 shows the yields of reaction products by pyrolysis of Açaí seeds carried out in different production scales (laboratory, bench, and pilot), using reactors of 140, 1500, and $143,000 \mathrm{~mL}$, that is, volume scales of approximately $\approx 1: 10: 1000$ [77]. One observes that the yield of bio-oil lies between 4.37 and 13.09 (wt.\%), decreasing with increasing reactor volume, while the yields of coke and gas increase with increasing reactor volume. Since the pyrolysis experiments in different production scales used no mechanical stirring system, the higher the reactor volume, the worse the energy transport by conduction in the solid phase (seeds) and convection in the fluid phase (air), and hence the lower the carbonization grad of biomass. The lower the carbonization grade of biomass, the lower the bio-oil yield. This explains a decrease of bio-oil yield with increasing reactor volume. The yield of gas ranged from 24.14 to 27.0 (wt.\%), showing no differences between laboratory and bench scales and an increment of $\sim 10 \%$ compared to the pilot scale.

\subsubsection{Physical-Chemistry Characterization of Bio-Oil}

The physico-chemical properties of bio-oil obtained by pyrolysis of dried Açaí (Euterpe oleracea Mart.) seeds at $450{ }^{\circ} \mathrm{C}$ and 1.0 atmosphere, in different production scales (laboratory, bench, and pilot), are illustrated in Table 3. The measured bio-oil density in pilot scale was $1.043 \mathrm{~g} / \mathrm{mL}$, close to the density of $\left(1.066 \mathrm{~g} / \mathrm{mL}, 20{ }^{\circ} \mathrm{C}\right)$ softwood bark residues bio-oil [21], and the density of $\left(1.030 \mathrm{~g} / \mathrm{mL}, 20^{\circ} \mathrm{C}\right)$ palm empty fruit bunches bio-oil [81]. The bio-oil density was lower than the densities of corn Stover bio-oil [25], rice husk bio-oils [28,41,69], and loblolly pine wood chips bio-oil [82]. This is probably due to the high hydrocarbon content in bio-oil [35], but also due to the absence of dissolved acidified aqueous phase in bio-oil after the separation and purification steps of decantation and filtration [35]. 
Table 2. Mass balances, process conditions, and yields of reaction products (coke, bio-oil, $\mathrm{H}_{2} \mathrm{O}$, and gas) in laboratory, bench, and pilot scales.

\begin{tabular}{cccc}
\hline & \multicolumn{3}{c}{ Temperature } \\
\hline Process Parameters & $\mathbf{4 5 0}\left({ }^{\circ} \mathbf{C}\right)$ & $\mathbf{4 5 0}\left({ }^{\circ} \mathbf{C}\right)$ & $\mathbf{4 5 0}\left({ }^{\circ} \mathbf{C}\right)$ \\
\cline { 2 - 4 } & Pilot & Bench & Laboratory \\
\hline Mass of Açaí Seeds $(\mathrm{kg})$ & 30 & $900 \times 10^{-3}$ & $50.49 \times 10^{-3}$ \\
Mass of LPG $(\mathrm{g})$ & 13.33 & - & - \\
Cracking Time $(\mathrm{min})$ & 160 & 90 & 53 \\
Initial Cracking Temperature $\left({ }^{\circ} \mathrm{C}\right)$ & 117 & 115 & 310 \\
Mass of Liquid (Bio-Oil $\left.+\mathrm{H}_{2} \mathrm{O}\right)(\mathrm{kg})$ & 11.40 & $394.07 \times 10^{-3}$ & $24.95 \times 10^{-3}$ \\
Mass of Coke $(\mathrm{kg})$ & 10.50 & $283.97 \times 10^{-3}$ & $13.35 \times 10^{-3}$ \\
Mass of Bio-Oil $(\mathrm{kg})$ & 1.31 & $50.40 \times 10^{-3}$ & $6.61 \times 10^{-3}$ \\
Mass of $\mathrm{H}_{2} \mathrm{O}(\mathrm{kg})$ & 10.09 & $343.67 \times 10^{-3}$ & $18.34 \times 10^{-3}$ \\
Mass of Gas $(\mathrm{kg})$ & 8.10 & $221.96 \times 10^{-3}$ & $12.19 \times 10^{-3}$ \\
Yield of Bio-Oil $(\mathrm{wt} \%)$ & 4.37 & 6.60 & 13.09 \\
Yield of Coke $(\mathrm{wt} \%)$ & 35.00 & 31.55 & 26.44 \\
Yield of $\mathrm{H}_{2} \mathrm{O}(\mathrm{wt} . \%)$ & 33.63 & 38.19 & 36.32 \\
Yield of Gas $(\mathrm{wt} . \%)$ & 27.00 & 24.66 & 24.14 \\
\hline
\end{tabular}

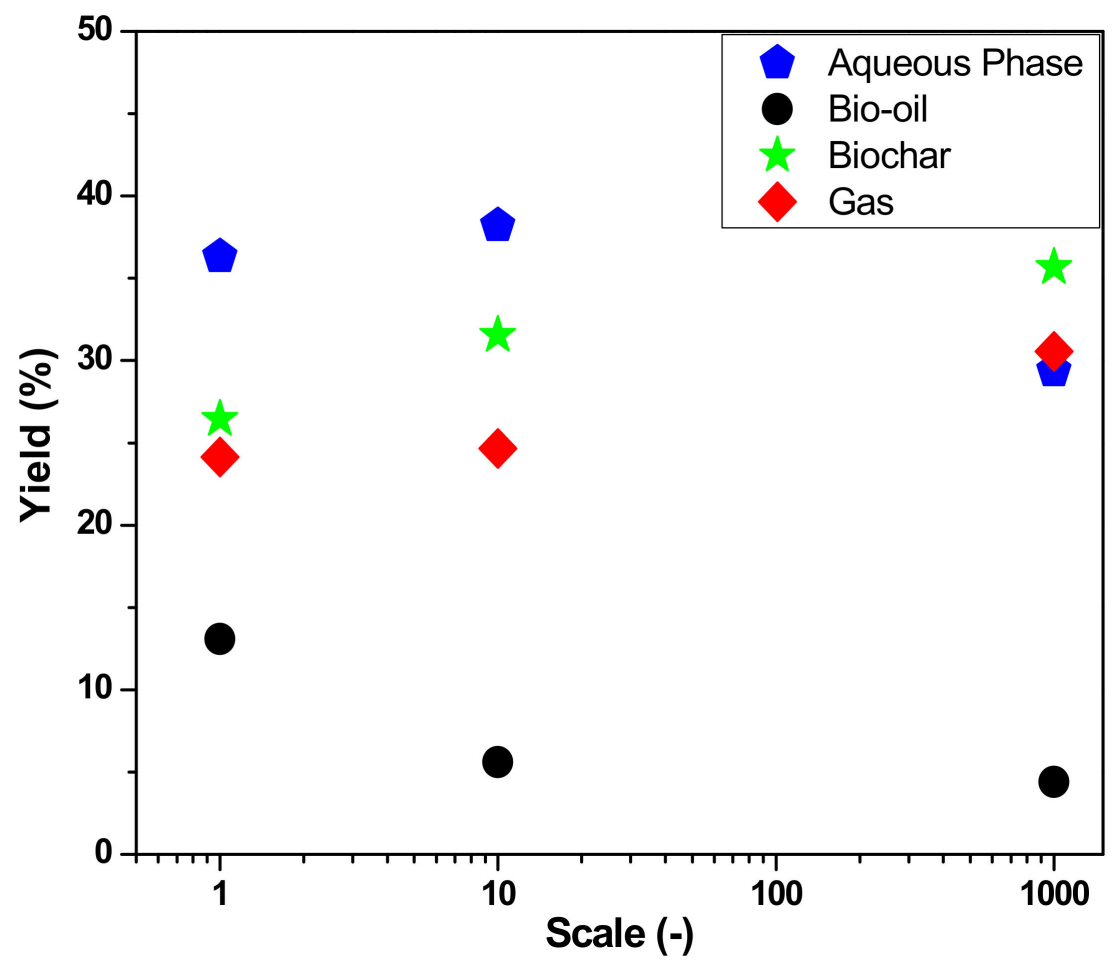

Figure 7. Yields of reaction products in laboratory, bench, and pilot scales.

Table 3. Physico-chemical properties of bio-oil obtained by pyrolysis of dried Açaí seeds at $450{ }^{\circ} \mathrm{C}$ and 1.0 atmosphere, compared to similar data reported in the literature $[21,25,28,41,69,81,82]$.

\begin{tabular}{|c|c|c|c|c|c|c|c|c|c|c|c|}
\hline \multirow{2}{*}{$\begin{array}{l}\text { Physicochemical } \\
\text { Properties }\end{array}$} & $\begin{array}{c}450^{\circ} \mathrm{C} \\
\text { Pilot }\end{array}$ & $\begin{array}{c}450^{\circ} \mathrm{C} \\
\text { Laboratory }\end{array}$ & $\begin{array}{l}450^{\circ} \mathrm{C} \\
\text { Bench }\end{array}$ & [21] & [25] & [28] & [41] & [69] & [82] & [81] & \multirow{2}{*}{ ANP No 65} \\
\hline & Bio-Oil & Bio-Oil & Bio-Oil & Bio-Oil & Bio-Oil & Bio-Oil & Bio-Oil & Bio-Oil & Bio-Oil & Bio-Oil & \\
\hline$\rho$ & 1.043 & ND & ND & 1.066 & 1.250 & 1.140 & 1.190 & 1.1581 & 1.200 & 1.030 & $0.82-0.85$ \\
\hline I. A (m & 70.26 & $70.25 \pm 1.00$ & $68.31 \pm 0.90$ & - & . & . & - & - & 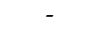 & & - \\
\hline$v\left(\mathrm{~mm}^{2} / \mathrm{s}\right), 40^{\circ} \mathrm{C}$ & 68.34 & ND & ND & 38.0 & 148.0 & 13.2 & $40.0^{*}$ & $5.0-13.0$ & 12.0 & - & $2.0-4.5$ \\
\hline
\end{tabular}

I.A = Acid Value; ANP: Brazilian National Petroleum Agency, Resolution No 65 (Specification of Diesel S10); ND = Not Determined.

* (Measured at $60^{\circ} \mathrm{C}$ ). 
The Açaí seeds' bio-oil viscosity $\left(68.34 \mathrm{~mm}^{2} / \mathrm{s}\right)$ is lower than that of $\left(148 \mathrm{~mm}^{2} / \mathrm{s}\right.$, $\left.60{ }^{\circ} \mathrm{C}\right)$ corn Stover [25]. The bio-oil viscosity $\left(68.34 \mathrm{~mm}^{2} / \mathrm{s}\right)$ is higher than those of $\left(38.0 \mathrm{~mm}^{2} / \mathrm{s}\right)$ softwood bark residues [21], $\left(13.2 \mathrm{~mm}^{2} / \mathrm{s}\right)$ rice husk [28], $\left(40.0 \mathrm{~mm}^{2} / \mathrm{s}\right.$, $\left.60{ }^{\circ} \mathrm{C}\right)$ rice husk [41], $\left(5.0-13.0 \mathrm{~mm}^{2} / \mathrm{s}, 40^{\circ} \mathrm{C}\right)$ rice husk [69], and $\left(12.0 \mathrm{~mm}^{2} / \mathrm{s}, 40{ }^{\circ} \mathrm{C}\right)$ loblolly pine wood chips [82]. The results for density and kinematic viscosity are according to similar data reported elsewhere [27], where average density of wood bio-oil is $1.2 \mathrm{~g} / \mathrm{cm}^{3}$ and the kinematic viscosity of wood bio-oils at 40 and $50{ }^{\circ} \mathrm{C}$ lies between 40 and $150 \mathrm{~mm}^{2} / \mathrm{s}[21,25,28,41,69,81,82]$.

The effect of reactor scale on the acid value of bio-oil by pyrolysis of Açaí seeds pyrolysis at $450{ }^{\circ} \mathrm{C}$ and 1.0 atmosphere, in laboratory, bench, and pilot scales illustrated in Figure 8. The acid value of bio-oils ranged from 68.31 to 70.26 (wt.\%), showing no significant differences between laboratory, bench, and pilot scales.

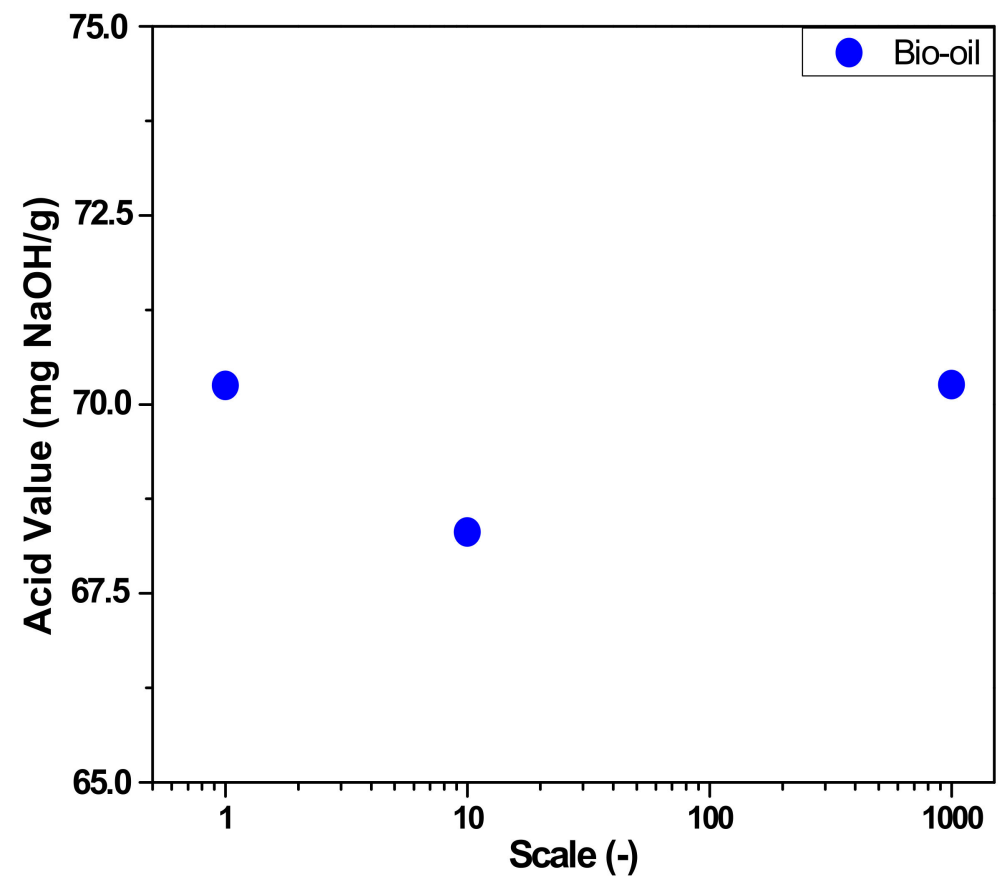

Figure 8. Acid value of bio-oil by pyrolysis of Açaí seeds pyrolysis at $450{ }^{\circ} \mathrm{C}$ and 1.0 atmosphere, in laboratory, bench, and pilot scales.

The acid value of bio-oils obtained by pyrolysis of dried Açaí seeds at $450{ }^{\circ} \mathrm{C}$ and 1.0 atmosphere, in different production scales (laboratory, bench, and pilot), summarized in Table 4, showed no significate deviation, varying between 67.41 and $71.25 \mathrm{mg} \mathrm{KOH} / \mathrm{g}$, close to the acid value of $(70.50 \mathrm{mg} \mathrm{KOH} / \mathrm{g}$ ) corn Stover bio-oil [43]. The acid value of biooils were lower than that of $(95.0 \mathrm{mg} \mathrm{KOH} / \mathrm{g})$ corncobs [43], $(82.0 \mathrm{mg} \mathrm{NaOH} / \mathrm{g})$ sugarcane bagasse [83], Douglas fir (124.0 mg KOH/g) [84], Hardwood (91.7 mg KOH/g) [84], oak (133.0 mg KOH/g) [84], poplar (129.0 mg KOH/g) [84], pine (91.6 mg KOH/g) [84], softwood (115.0 mg KOH/g) [84], switch-grass (125.0 mg KOH/g) [84], and wheat straw (94.9 $\mathrm{mg} \mathrm{KOH} / \mathrm{g})$ [84], and higher than the acid value of $(47.7 \mathrm{mg} \mathrm{NaOH} / \mathrm{g})$ softwood bark bio-oil [85], and the acid value of $(24.0 \mathrm{mg} \mathrm{KOH} / \mathrm{g})$ corn Stover bio-oil [48]. The high acidity of bio-oils is due to the presence of oxygenates compounds, such as carboxylic acids, phenols, cresols, ketones, and aldehydes [35]. This is according to the results reported by Oasma et al. [34], who stated that acidity of fast pyrolysis bio-oils, is due to not only volatile carboxylic acids but also other functional groups such as phenols, resin acids, and hydroxyl acids [34]. 
Table 4. Acid value of bio-oil obtained by pyrolysis of dried Açaí seeds at $450{ }^{\circ} \mathrm{C}$ and 1.0 atmosphere, compared to similar data reported in the literature [43,48,83-85].

\begin{tabular}{|c|c|c|c|c|c|c|c|c|c|c|c|c|c|c|c|}
\hline & $\begin{array}{c}450^{\circ} \mathrm{C} \\
\text { Pilot }\end{array}$ & $\begin{array}{c}450^{\circ} \mathrm{C} \\
\text { Laboratory }\end{array}$ & $\begin{array}{l}450^{\circ} \mathrm{C} \\
\text { Bench }\end{array}$ & [43] & {$[48]$} & [83] & [84] & {$[84]$} & [84] & [84] & {$[84]$} & [84] & [84] & [84] & [85] \\
\hline $\begin{array}{l}\text { Physicochemical } \\
\text { Properties }\end{array}$ & $\begin{array}{l}\overline{0} \\
\vdots \\
\vdots \\
\dot{0}\end{array}$ & 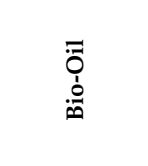 & 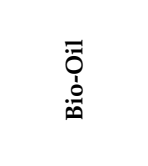 & $\begin{array}{l}\text { ö } \\
\vdots \\
\vdots \\
0\end{array}$ & 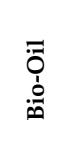 & $\begin{array}{l}\overline{0} \\
\vdots \\
\vdots \\
0\end{array}$ & 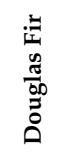 & 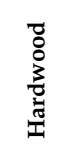 & ฮँ & $\begin{array}{l}\frac{\pi}{0} \\
\frac{0}{2} \\
2\end{array}$ & $\Xi$ & 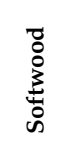 & 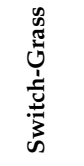 & $\begin{array}{l}3 \\
\frac{3}{5} \\
\omega \\
\frac{\pi}{\pi} \\
\frac{5}{3}\end{array}$ & $\begin{array}{l}\overline{0} \\
\stackrel{0}{0} \\
\dot{0}\end{array}$ \\
\hline I. A $[\mathrm{mg} \mathrm{KOH} / \mathrm{g}]$ & 70.26 & $70.25 \pm 1.00$ & $68.31 \pm 0.90$ & 95.00 & 24.00 & 82.00 & 124.00 & 91.70 & 133.00 & 129.00 & 91.60 & 115.00 & 125.00 & 94.90 & 47.70 \\
\hline
\end{tabular}

I.A = Acid Value.

\subsection{Distillation of Bio-Oil from Pyrolysis of Açaí Seeds}

Table 5 summarizes the material balance and yields by fractional distillation of bio-oil, and the distillation fractions and bottoms are illustrated in Figure 9. The yields of fuel-like fractions (gasoline, light kerosene, and kerosene) were 16.16, 19.56, and 41.89 (wt.\%), respectively, giving a total distillation yield of 77.61 (wt.\%). The results are according to similar studies for distillation of biomass derived bio-oil in the literature [17-19,21,41,46-48,53,66,70,72]. The yield of distillation fractions is higher than those reported in the literature for both atmospheric and vacuum conditions $[17-19,21,41,46-48,53,66,70,72]$.

Table 5. Material balance and yields by fractional distillation of bio-oil.

\begin{tabular}{|c|c|c|c|c|c|c|c|c|c|c|c|c|c|}
\hline \multirow{2}{*}{$\begin{array}{c}\text { Distillation: } \\
\text { Vigreux Column }\end{array}$} & \multirow{2}{*}{$\frac{\text { Bio-Oil (g) }}{\text { (g) }}$} & \multirow{2}{*}{$\begin{array}{l}\text { Gas } \\
\text { (g) }\end{array}$} & \multirow{2}{*}{$\begin{array}{c}\text { Raffinate } \\
\text { (g) }\end{array}$} & \multicolumn{5}{|c|}{ Distillates (g) } & \multicolumn{5}{|c|}{ Yield (wt.\%) } \\
\hline & & & & $\mathrm{H}_{2} \mathrm{O}$ & G & LK & $\mathbf{K}$ & LD & $\mathrm{H}_{2} \mathrm{O}$ & G & LK & K & LD \\
\hline$\left(30-215^{\circ} \mathrm{C}\right)$ & 307.53 & 0 & 69.87 & 0 & 49.48 & 59.91 & 128.27 & 0 & 0 & 16.16 & 19.56 & 41.89 & 0 \\
\hline
\end{tabular}

$\mathrm{G}=$ Gasoline, $\mathrm{LK}=$ Light Kerosene, $\mathrm{K}=$ Kerosene, $\mathrm{LD}=$ Light Diesel.

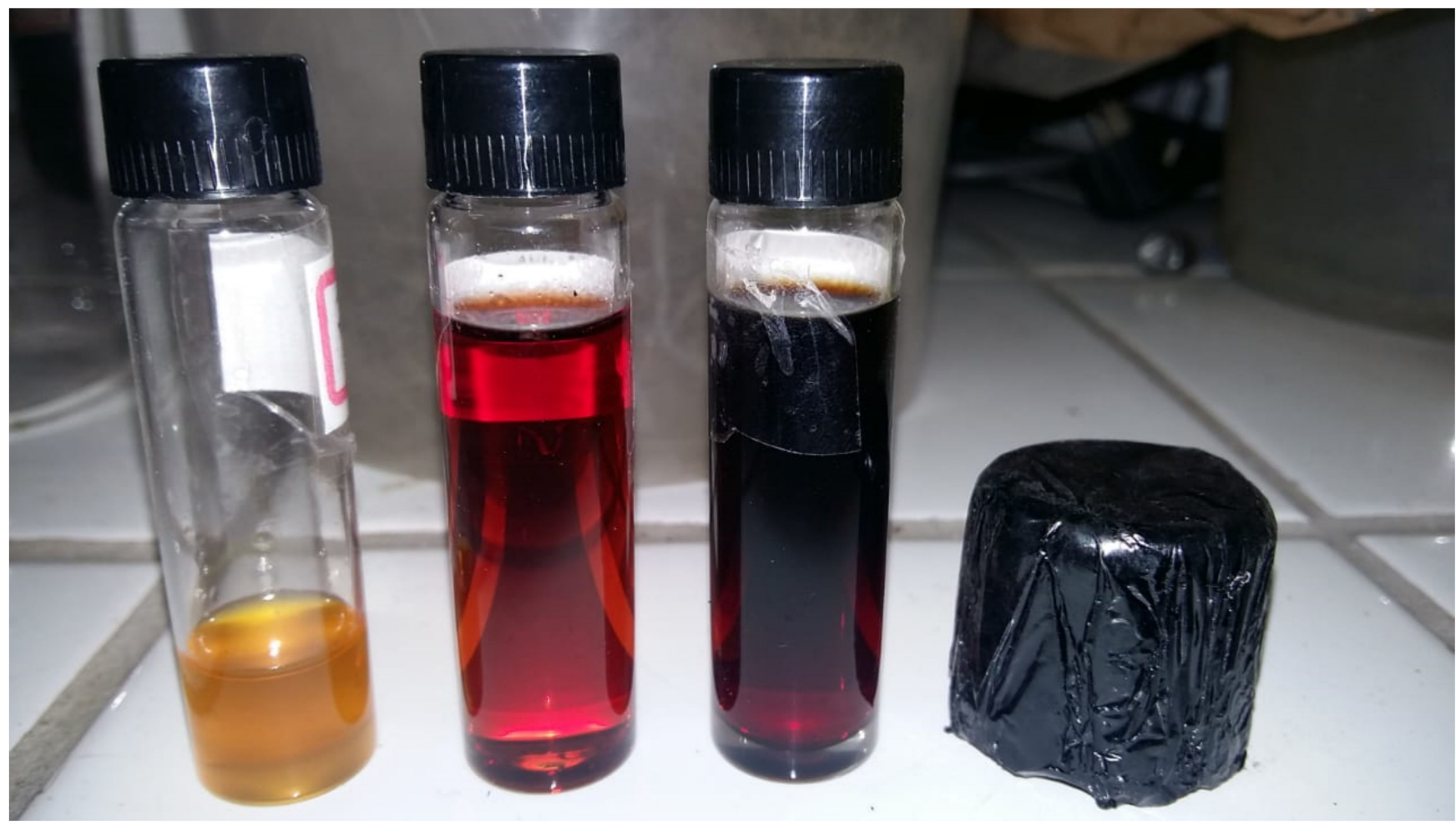

Figure 9. Distillation fractions [gasoline (yellow), light kerosene (red), and kerosene (red dark)-like boiling range temperature fossil fuels] and bottoms [Raffinate (black solid)] obtained by fractional distillation of bio-oil produced by pyrolysis of Açaí (Euterpe oleracea, Mart.) seeds at $450{ }^{\circ} \mathrm{C}$ and 1.0 atmosphere, in pilot scale. 
Zheng and Wei [41] reported distillation of fast pyrolysis bio-oil at $80{ }^{\circ} \mathrm{C}$ under vacuum $(15 \mathrm{mmHg})$ and a distilled bio-oil yield of 61 (wt.\%). Zhang et al. [47] reported atmospheric distillation of fast pyrolysis bio-oil, an accumulated distillate of 51.86 (wt.\%). Zhang et al. [47] observed that as the distillation temperature reached $240{ }^{\circ} \mathrm{C}$, condensation reactions take place, generating water, a behavior not observed during the course of distillation as illustrated in Table 5. Capunitan and Capareda [48] reported, for the distillation in atmospheric conditions, an organic phase (Distillates) yield of 15.0 (wt.\%) at $100{ }^{\circ} \mathrm{C}, 4.7$ (wt.\%) between $100{ }^{\circ} \mathrm{C}<\mathrm{T}^{\text {Boiling }}<180{ }^{\circ} \mathrm{C}$, and 45.3 (wt.\%) between $180{ }^{\circ} \mathrm{C}<\mathrm{T}^{\text {Boiling }}<250{ }^{\circ} \mathrm{C}$, while vacuum distillation yielded 10.3 (wt.\%) of an organic phase at $80{ }^{\circ} \mathrm{C}, 5.9$ (wt.\%) between $80{ }^{\circ} \mathrm{C}<\mathrm{T}^{\text {Boiling }}<160{ }^{\circ} \mathrm{C}$, and 40.9 (wt. \%) between $160{ }^{\circ} \mathrm{C}<\mathrm{T}^{\text {Boiling }}<230{ }^{\circ} \mathrm{C}$. Elkasabi et al. [53] reported by distillation of tail-gas reactive pyrolysis (TGRP) bio-oil, yields ranging from 55 to 65 (wt.\%).

Physico-Chemical Characterization of Distillation Fractions

The physical-chemical properties of distillation fractions (gasoline, $80-175{ }^{\circ} \mathrm{C}$; light kerosene, $175-20{ }^{\circ} \mathrm{C}$; and kerosene-like fraction, $200-215^{\circ} \mathrm{C}$ ) of bio-oil are illustrated in Table 6.

Table 6. Physico-chemical properties of distillation fractions of bio-oil produced by pyrolysis of Açaí seeds at $450{ }^{\circ} \mathrm{C}$ and 1.0 atmosphere, in pilot scale.

\begin{tabular}{ccccc}
\hline \multirow{2}{*}{$\begin{array}{c}\text { Physico-Chemical } \\
\text { Properties }\end{array}$} & $\mathbf{G}$ & $\mathbf{4 K}$ & $\mathbf{4}{ }^{\circ} \mathbf{C}$ & ANP N $^{\circ} \mathbf{6 5}$ \\
\cline { 2 - 5 } & 0.9146 & 0.9191 & 0.9816 & $0.82-0.85$ \\
$\rho\left(\mathrm{g} / \mathrm{cm}^{3}\right), 30{ }^{\circ} \mathrm{C}$ & 14.94 & 61.08 & 64.78 & \\
$\mathrm{I} . \mathrm{A}(\mathrm{mg} \mathrm{KOH} / \mathrm{g})_{\mathrm{I} \mathrm{R}(-)}$ & 1.455 & 1.479 & 1.497 & \\
$v\left(\mathrm{~mm}^{2} / \mathrm{s}\right), 40{ }^{\circ} \mathrm{C}$ & 1.457 & 3.106 & 4.040 & $2.0-4.5$ \\
\hline
\end{tabular}

I.A = Acid Value, I.R = Refractive Index.

It can be observed that acidity of distillation fractions increases with boiling temperature. However, the acidity of gasoline-like fraction is much lower than that of raw bio-oil (70.26 mg KOH/g), as described in Table 4 . The high acid value of bio-oil is due to the presence of 78.48 (area.\%) oxygenates [35]. The same behavior was observed for the densities, kinematic viscosities, and refractive indexes of gasoline, light kerosene, and kerosene-like like fractions with increasing boiling temperature. This is probably due to the high concentration of higher-boiling-point compounds in the distillate fractions, such as phenols, cresols ( $p$-cresol, $o$-cresol), and furans [35], as the concentration of those compounds in the distillation fractions increases with increasing boiling temperature as reported elsewhere $[35,66,70,72]$.

The gasoline, light-kerosene, and kerosene-like fuel densities were 0.9146, 09191, and $0.9816 \mathrm{~g} / \mathrm{mL}$. The gasoline-like fuel density (fractions $\left(40{ }^{\circ} \mathrm{C}<\mathrm{T}^{\text {Boiling }}<175{ }^{\circ} \mathrm{C}\right.$ ), higher, but close to the density of distillation fraction of $0.8733 \mathrm{~g} / \mathrm{mL}\left(\mathrm{T}^{\text {Boiling }}<140{ }^{\circ} \mathrm{C}\right)$ for jatropha curcas cake pyrolysis bio-oil reported by Majhi et al. [46]. This is probably due to the high lipids content between 14-18 (wt.\%) and 10-10.9 (wt.\%) fiber, thus producing a bio-oil similar to lipid-based pyrolysis organic liquid products $[77,78]$. The gasoline, lightkerosene, and kerosene-like fuel kinematic viscosities were $1.457,3.106$, and $4.040 \mathrm{~mm}^{2} / \mathrm{s}$, lower than the distillation fraction kinematic viscosity of $2.350 \mathrm{~mm}^{2} / \mathrm{s}\left(\mathrm{T}^{\text {Boiling }}<140{ }^{\circ} \mathrm{C}\right)$ for jatropha curcas cake pyrolysis bio-oil reported by Majhi et al. [46].

The acid value of gasoline, light-kerosene, and kerosene-like fuel fractions were 14.94, 61.08 , and $64.78 \mathrm{mg} \mathrm{KOH} / \mathrm{g}$, lower than the distillation fraction acid value of $0.05 \mathrm{mg}$ $\mathrm{KOH} / \mathrm{g}\left(\mathrm{T}^{\text {Boiling }}<140{ }^{\circ} \mathrm{C}\right)$ for jatropha curcas cake pyrolysis bio-oil distillation reported by Majhi et al. [46], the organic phases (distillates) acid values of $4.1\left(100{ }^{\circ} \mathrm{C}<\mathrm{T}^{\text {Boiling }}\right), 15.1$ $\left(100{ }^{\circ} \mathrm{C}<\mathrm{T}^{\text {Boiling }}<180{ }^{\circ} \mathrm{C}\right)$, and $7.41\left(180^{\circ} \mathrm{C}<\mathrm{T}^{\text {Boiling }}<250^{\circ} \mathrm{C}\right) \mathrm{mg} \mathrm{KOH} / \mathrm{g}$, for corn Stover bio-oil atmospheric distillation reported by Capunitan and Capareda [48], the organic phases (distillates) acid values of $3.0\left(80^{\circ} \mathrm{C}<\mathrm{T}^{\text {Boiling }}\right), 13.9\left(80^{\circ} \mathrm{C}<\mathrm{T}^{\text {Boiling }}<160{ }^{\circ} \mathrm{C}\right)$, and 5.0 
$\left(160{ }^{\circ} \mathrm{C}<\mathrm{T}^{\text {Boiling }}<230{ }^{\circ} \mathrm{C}\right) \mathrm{mg} \mathrm{KOH} / \mathrm{g}$, for corn Stover bio-oil vacuum distillation reported by Capunitan and Capareda [48], the acid values of $13.5 \mathrm{mg} \mathrm{KOH} / \mathrm{g}\left(\mathrm{T}^{\text {Boiling }}=192{ }^{\circ} \mathrm{C}\right)$ and $5.3 \mathrm{mg} \mathrm{KOH} / \mathrm{g}\left(\mathrm{T}^{\text {Boiling }}=220^{\circ} \mathrm{C}\right)$ of distillation fractions $\mathrm{F}_{3}$ and $\mathrm{F}_{4}$ of $\mathrm{TGRP}_{1}$, and the acid value of $11.1 \mathrm{mg} \mathrm{KOH} / \mathrm{g}\left(\mathrm{T}^{\text {Boiling }}=235^{\circ} \mathrm{C}\right)$ of distillation fraction $\mathrm{F}_{5}$ of $\mathrm{TGRP}_{2}$, for tail-gas reactive pyrolysis of horse manure $\left(\mathrm{TGRP}_{1}\right)$, switch grass $\left(\mathrm{TGRP}_{2}\right)$, and eucalyptus $\left(\mathrm{TGRP}_{3}\right)$, reported by Elkasabi et al. [53].

The results reported by Elkasabi et al. [53], show that fractional distillation was not effective to diminish the acid values of TGRP bio-oil with initial high acid values, what does not agree with the results reported by Capunitan and Capareda [48], as well as those presented in Table 6, showing that the acid values of distillation fractions are lower than that of raw bio-oil, proving that distillation was effective.

\subsection{FT-IR and GC-MS Analyses of Bio-Oil and Distillation Fractions \\ 3.4.1. FT-IR Spectroscopy of Bio-Oil and Distillation Fractions}

The FT-IR analysis of bio-oils obtained by pyrolysis of Açaí seeds pyrolysis at $450{ }^{\circ} \mathrm{C}$ and 1.0 atmosphere, in laboratory, bench, and pilot scales, summarized in Figure 10, and the infrared bands representing the functional groups in Table 7 . The identification of absorption bands/peaks was performed according to previous studies [28,48,59,73,77-80,82]. The FT-IR spectroscopy of bio-oils identify the presence of hydrocarbons (alkanes, alkenes, and aromatic hydrocarbons) and oxygenates (phenols, cresols, carboxylic acids, alcohols, ethers, ketones, and furans).

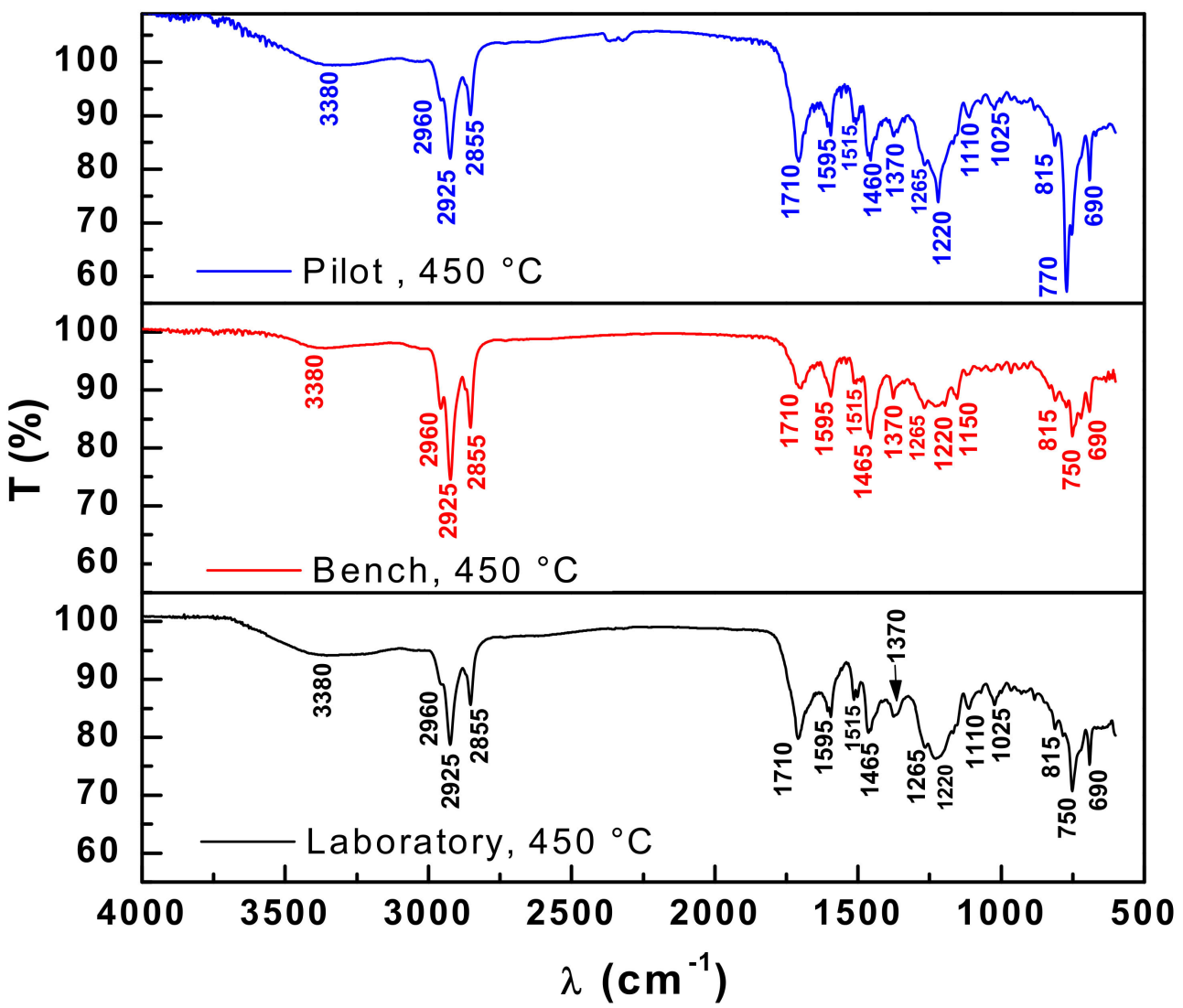

Figure 10. FT-IR of bio-oil obtained by pyrolysis of Açaí seeds pyrolysis at $450{ }^{\circ} \mathrm{C}$ and 1.0 atmosphere, in laboratory, bench, and pilot scales. 
Table 7. Infrared bands identified in the bio-oils obtained by pyrolysis of Açaí seeds pyrolysis at $450{ }^{\circ} \mathrm{C}$ and 1.0 atmosphere, in laboratory, bench, and pilot scales.

\begin{tabular}{|c|c|c|c|c|}
\hline \multirow{2}{*}{ Wave-Length $\left(\mathrm{cm}^{-1}\right)$} & \multirow{2}{*}{ Functional Groups } & \multicolumn{3}{|c|}{ Bio-Oil } \\
\hline & & $450{ }^{\circ} \mathrm{C}$ Pilot & $450^{\circ} \mathrm{C}$ Bench & $450^{\circ} \mathrm{C}$ Laboratory \\
\hline 3380 & O-H hydroxyl (polymeric association) & $X$ & $X$ & $X$ \\
\hline $2960-2855$ & C-H aliphatics (alkanes) & $X$ & $X$ & $X$ \\
\hline 1710 & $\mathrm{C}=\mathrm{O}$ carbonyl (carboxylic acids) & $x$ & $x$ & $x$ \\
\hline 1595-1510 & $\mathrm{C}=\mathrm{C}($ Aromatic $)$ & $X$ & $X$ & $X$ \\
\hline $1455-1465$ & $-\mathrm{CH}_{2}$ - angular deformation (methylene groups) & $X$ & $X$ & $X$ \\
\hline 1370 & $\mathrm{CH}_{3}$ angular deformation (dimethyl groups) & $x$ & $X$ & $X$ \\
\hline $1275-1020$ & C-O (esters, ethers, alcohols and phenols) & $x$ & $x$ & $x$ \\
\hline $1225-1220$ & $\mathrm{C}-\mathrm{O}$ (phenols) & $X$ & $X$ & $X$ \\
\hline 1150 & C-O (tertiary alcohol) & - & $X$ & - \\
\hline 1110 & C-O (secondary alcohol) & $X$ & - & $X$ \\
\hline $815-690$ & $\mathrm{C}=\mathrm{C}$ (adjacent $3 \mathrm{H}$ aromatic rings) & $x$ & $x$ & $x$ \\
\hline
\end{tabular}

Figure 11 illustrates the FT-IR analysis of bio-oil obtained by pyrolysis of Açaí seeds pyrolysis at $450^{\circ} \mathrm{C}$ and 1.0 atmosphere, in pilot scale, and the distillation fractions (gasoline: $40-175{ }^{\circ} \mathrm{C}$, light kerosene: $175-200{ }^{\circ} \mathrm{C}$, and kerosene-like fraction: $200-215{ }^{\circ} \mathrm{C}$ ). The absorption bands/peaks identified according to previous studies [28,48,59,73,77-80,82]. The FT-IR spectroscopy of bio-oil and distillation fraction identify the presence of hydrocarbons (alkanes, alkenes, and aromatic hydrocarbons) and oxygenates (phenols, cresols, carboxylic acids, alcohols, ethers, ketones, and furans).

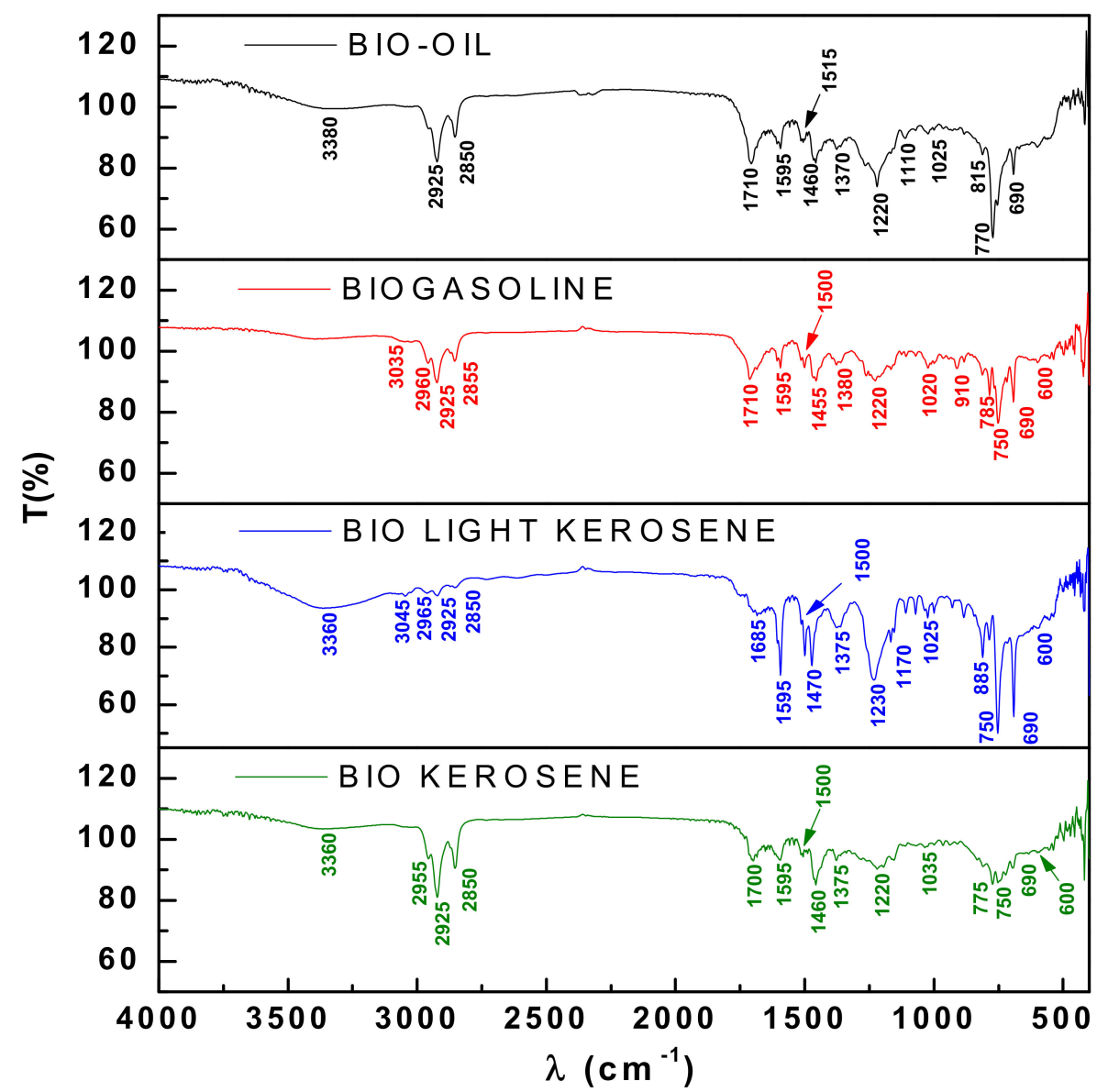

Figure 11. FT-IR of bio-oil obtained by pyrolysis of Açaí seeds pyrolysis at $450{ }^{\circ} \mathrm{C}$ and 1.0 atmosphere, in pilot scale, and the distillation fractions (gasoline: $40-175{ }^{\circ} \mathrm{C}$, light kerosene: $175-200{ }^{\circ} \mathrm{C}$, and kerosene-like fraction: $200-215^{\circ} \mathrm{C}$ ). 


\subsubsection{Chemical Compositional of Bio-Oil and Distillation Fractions by GC-MS} Chemical Compositional of Bio-Oils by GC-MS

The chromatograms of bio-oils obtained by pyrolysis of Açaí seeds pyrolysis at $450{ }^{\circ} \mathrm{C}$ and 1.0 atmosphere, in bench and pilot scales is shown in Figure 12. The peaks are concentrated between retention times of 8.0 and $22.0 \mathrm{~min}$, with the highest one around $12.5 \mathrm{~min}$ for the bio-oil obtained pilot scale, while that obtained in bench scale, the peaks are concentrated between retention times of 7.0 and $18.0 \mathrm{~min}$. The GC-MS identified hydrocarbons (alkanes, alkenes, aromatic hydrocarbons, and cycloalkenes) and oxygenates (esters, phenols, cresols, carboxylic acids, ketones, furans, and aldehydes) in bio-oils. The GC-MS identified 48.24 (area.\%) hydrocarbons and 51.76 (area.\%) oxygenates in the bio-oil in bench scale and 21.52 (area.\%) hydrocarbons and 78.48 (area.\%) oxygenates in the bio-oil in pilot scale, composed of 21.52 (area.\%) hydrocarbons and 78.48 (area.\%) oxygenates, as shown in Tables 8 and 9. The high acidity of both bio-oils, described in Table 4, is probably due to the presence of carboxylic acids, ketones, aldehydes, phenols, and cresols confer the high acidity of bio-oil.

The composition of bio-oil shows similarity to those reported in the literature $[27,34,41,47,48,53,61]$, showing the presence of hydrocarbons, phenols, cresols, furans, carboxylic acids, and esters, among other classes of compounds [73]. The identification of hydrocarbons with carbon chain length between $C_{11}$ and $C_{15}$, shows the presence of heavy gasoline compounds with $C_{11}\left(C_{5}-C_{11}\right)$, light kerosene-like fractions $\left(C_{11}-C_{12}\right)$, and light diesel-like fractions $\left(C_{13}-C_{15}\right)$, according to Tables 8 and 9 .

Chemical Compositional of Distillation Fractions by GC-MS

The chromatograms of bio-oil obtained in pilot scales and distillation fractions is shown in Figure 13. One observes that the spectrum of peaks is moving to the right, showing that distillation was effective to fractionate the bio-oil.

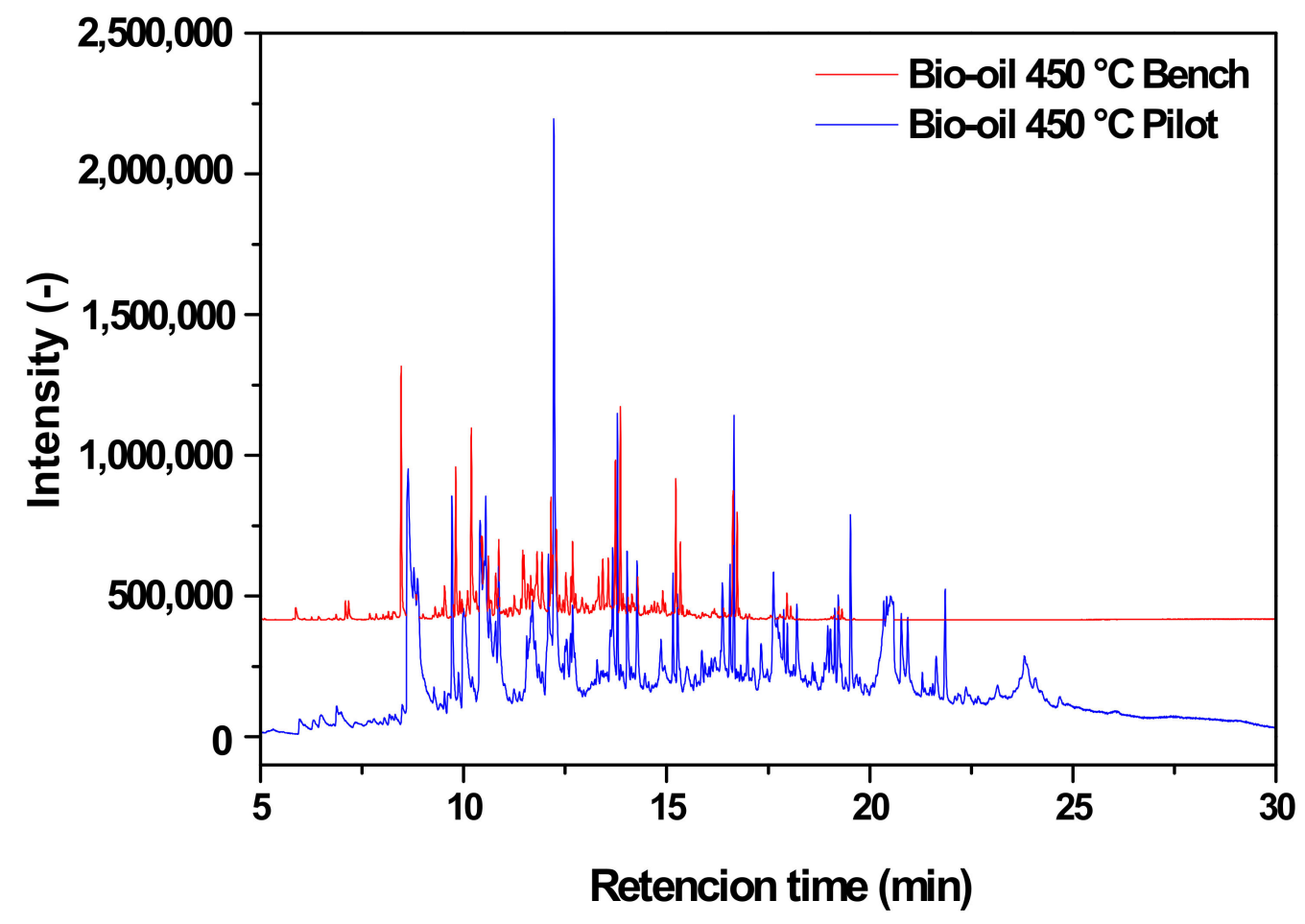

Figure 12. Chromatograms of bio-oils obtained in bench and pilot scales. 
Table 8. Classes of compounds and summation of peak areas of hydrocarbons and oxygenates identified by CG-MS in bio-oil obtained in pilot scale.

\begin{tabular}{|c|c|}
\hline Classes of Chemical Compounds & wi (Area.\%) \\
\hline \multicolumn{2}{|l|}{ Alkanes } \\
\hline$\Sigma($ Area. $\%)$ & 7.521 \\
\hline \multicolumn{2}{|l|}{ Alkenes } \\
\hline$\Sigma($ Area. $\%)$ & 2.118 \\
\hline \multicolumn{2}{|l|}{ Cycloalkenes } \\
\hline$\sum($ Area. \%) & 1.847 \\
\hline \multicolumn{2}{|l|}{ Aromatics } \\
\hline$\Sigma($ Area. \%) & 10.038 \\
\hline \multicolumn{2}{|l|}{ Esters } \\
\hline$\Sigma($ Area.\%) & 4.065 \\
\hline \multicolumn{2}{|l|}{ Carboxylic Acids } \\
\hline$\Sigma($ Area. $\%)$ & 8.523 \\
\hline \multicolumn{2}{|l|}{ Ketones } \\
\hline$\Sigma($ Area. \%) & 3.533 \\
\hline \multicolumn{2}{|l|}{ Phenols } \\
\hline$\Sigma($ Area. \%) & 35.167 \\
\hline \multicolumn{2}{|l|}{ Cresols } \\
\hline$\Sigma($ Area. $\%)$ & 20.526 \\
\hline \multicolumn{2}{|l|}{ Furans } \\
\hline$\Sigma($ Area. $\%)$ & 5.751 \\
\hline \multicolumn{2}{|l|}{ Aldehydes } \\
\hline$\Sigma($ Area. $\%)$ & 0.910 \\
\hline
\end{tabular}

Table 9. Classes of compounds and summation of peak areas of hydrocarbons and oxygenates identified by CG-MS in bio-oil obtained in bench scale.

\begin{tabular}{|c|c|}
\hline Classes of Chemical Compounds & wi (Area.\%) \\
\hline \multicolumn{2}{|l|}{ Alkanes } \\
\hline$\Sigma($ Area. \%) & 13.14 \\
\hline \multicolumn{2}{|l|}{ Alkenes } \\
\hline$\Sigma($ Area. \%) & 25.50 \\
\hline \multicolumn{2}{|l|}{ Aromatics } \\
\hline$\Sigma($ Area.\%) & 9.59 \\
\hline \multicolumn{2}{|l|}{ Alcohols } \\
\hline$\Sigma($ Area.\%) & 0.43 \\
\hline \multicolumn{2}{|l|}{ Ketones } \\
\hline$\Sigma($ Area. $\%)$ & 4.43 \\
\hline \multicolumn{2}{|l|}{ Phenols } \\
\hline$\Sigma($ Area. $\%)$ & 30.87 \\
\hline \multicolumn{2}{|l|}{ Furans } \\
\hline$\Sigma($ Area. $\%)$ & 15.24 \\
\hline \multicolumn{2}{|l|}{ Aldehydes } \\
\hline$\Sigma($ Area. $\%)$ & 0.80 \\
\hline
\end{tabular}

The GC-MS identified in gasoline-like fraction hydrocarbons and oxygenates. The gasoline-like fraction contains 64.0 (area.\%) hydrocarbons [13.27 (area.\%) alkenes, 9.41 (area.\%) alkanes, and 41.32 (area.\%) aromatic hydrocarbons] and 36.0 (area.\%) oxygenates [5.50 (area.\%) esters, 2.61 (area.\%) ketones, 1.35 (area.\%) phenols, 6.05 (area.\%) alcohols, 13.24 (area.\%) furans, and 7.25 (area.\%) aldehydes). The absence of carboxylic acids confers the low acidity of gasoline-like fraction, as summarized in Table 10. 


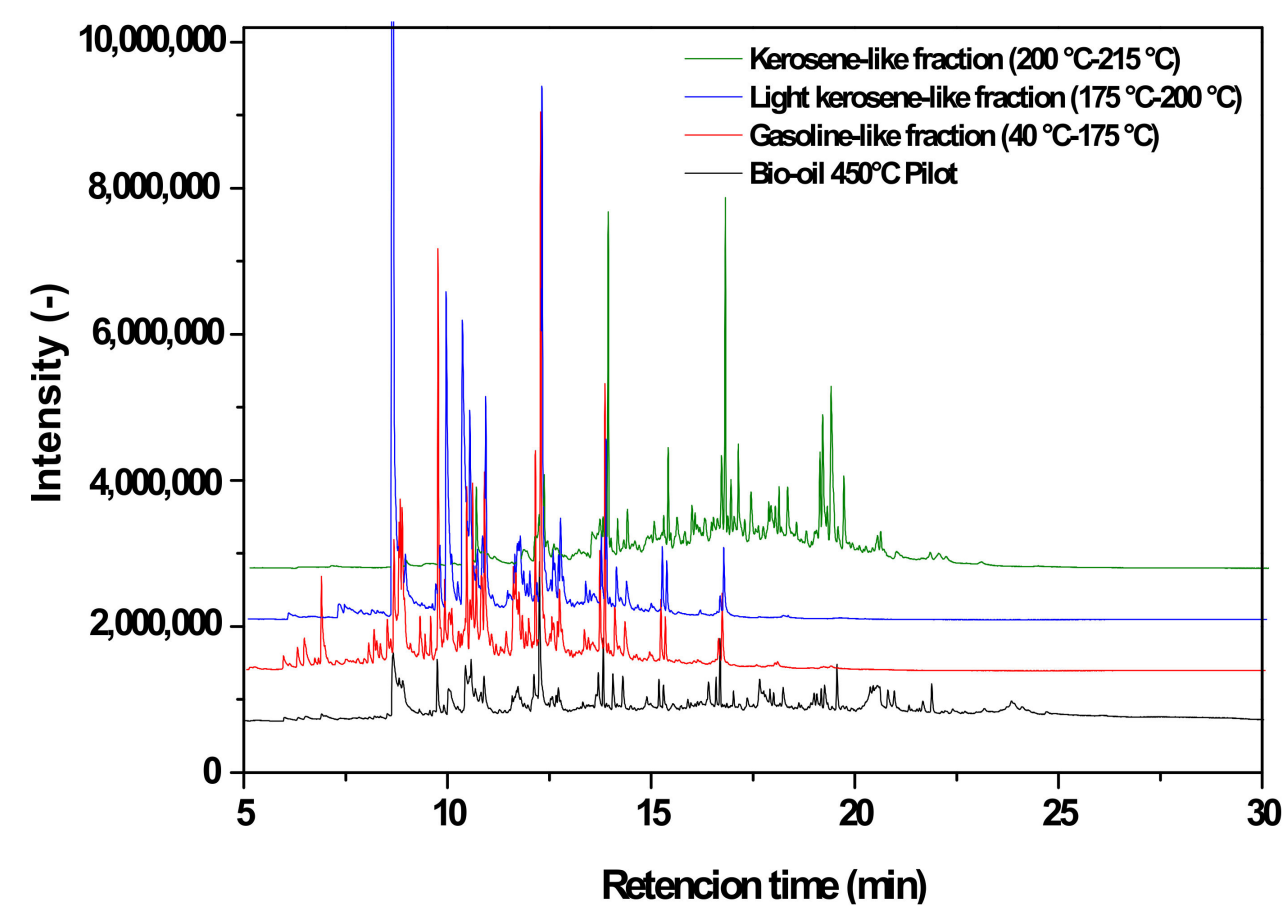

Figure 13. Chromatograms of bio-oil in pilot scale and distillation fractions.

Table 10. Classes of compounds and summation of peak areas of hydrocarbons and oxygenates identified by CG-MS in gasoline-like fraction $\left(40-175^{\circ} \mathrm{C}\right)$ after distillation of bio-oil obtained in pilot scale.

\begin{tabular}{|c|c|}
\hline Classes of Chemical Compounds & wi (Area.\%) \\
\hline \multicolumn{2}{|l|}{ Alkanes } \\
\hline$\Sigma($ Area. \%) & 9.41 \\
\hline \multicolumn{2}{|l|}{ Alkenes } \\
\hline$\Sigma($ Area. \%) & 13.27 \\
\hline \multicolumn{2}{|l|}{ Aromatics } \\
\hline$\Sigma($ Area. \%) & 41.32 \\
\hline \multicolumn{2}{|l|}{ Alcohols } \\
\hline$\Sigma($ Area. $\%)$ & 6.05 \\
\hline \multicolumn{2}{|l|}{ Esters } \\
\hline$\Sigma($ Area. \%) & 5.50 \\
\hline \multicolumn{2}{|l|}{ Ketones } \\
\hline$\Sigma($ Area. $\%)$ & 2.61 \\
\hline \multicolumn{2}{|l|}{ Phenols } \\
\hline$\Sigma($ Area. $\%)$ & 1.35 \\
\hline \multicolumn{2}{|l|}{ Furans } \\
\hline$\Sigma($ Area. \%) & 13.24 \\
\hline \multicolumn{2}{|l|}{ Aldehydes } \\
\hline$\Sigma($ Area. \%) & 7.25 \\
\hline
\end{tabular}

The light kerosene-like fraction is composed of 66.67 (area.\%) hydrocarbons [17.60 (area.\%) alkenes, 32.65 (area.\%) alkanes, and 16.42 (area.\%) aromatic hydrocarbons] and 33.33 (area.\%) oxygenates [6.16 (area.\%) esters, 4.24 (area.\%) ketones, 3.26 (area.\%) carboxylic acids, 7.13 (area.\%) phenols, 8.30 (area.\%) alcohols, 2.39 (area.\%) furans, and 1.86 (area.\%) aldehydes]. The presence of carboxylic acids, ketones, furans, and phenols is associated to the high acidity of light kerosene-like fraction, as shown in Table 11. 
Table 11. Classes of compounds and summation of peak areas of hydrocarbons and oxygenates identified by CG-MS in light-kerosene-like fraction $\left(175-200^{\circ} \mathrm{C}\right)$ after distillation of bio-oil obtained in pilot scale.

\begin{tabular}{|c|c|}
\hline Classes of Chemical Compounds & wi (Area.\%) \\
\hline \multicolumn{2}{|l|}{ Alkanes } \\
\hline$\Sigma($ Area. $\%)$ & 32.65 \\
\hline \multicolumn{2}{|l|}{ Alkenes } \\
\hline$\Sigma($ Area. \%) & 17.60 \\
\hline \multicolumn{2}{|l|}{ Aromatics } \\
\hline$\Sigma($ Area. $\%)$ & 16.42 \\
\hline \multicolumn{2}{|l|}{ Esters } \\
\hline$\Sigma($ Area. $\%)$ & 6.16 \\
\hline \multicolumn{2}{|l|}{ Carboxylic Acids } \\
\hline$\Sigma($ Area. $\%)$ & 3.26 \\
\hline \multicolumn{2}{|l|}{ Ketones } \\
\hline$\Sigma($ Area. $\%)$ & 4.24 \\
\hline \multicolumn{2}{|l|}{ Phenols } \\
\hline$\Sigma($ Area. $\%)$ & 7.13 \\
\hline \multicolumn{2}{|l|}{ Alcohols } \\
\hline$\Sigma($ Area. \%) & 8.30 \\
\hline \multicolumn{2}{|l|}{ Furans } \\
\hline$\Sigma($ Area. $\%)$ & 2.39 \\
\hline \multicolumn{2}{|l|}{ Aldehydes } \\
\hline$\Sigma($ Area. \%) & 1.86 \\
\hline
\end{tabular}

By the GC-MS analysis of kerosene-like fraction, hydrocarbons, and oxygenate were identified. The kerosene-like fraction contains 19.87 (area.\%) hydrocarbons [2.79 (area.\%) alkenes, 4.20 (area.\%) alkanes, and 12.88 (area.\%) aromatic hydrocarbons] and 81.13 (area.\%) oxygenates [2.06 (area.\%) esters, 0.80 (area.\%) ethers, 3.50 (area.\%) ketones, 60.79 (area.\%) phenols, 0.96 (area.\%) alcohols, 8.99 (area.\%) furans, and 3.22 (area.\%) aldehydes), as shown in Table 12. The presence of ketones, furans, ethers, esters, aldehydes, and phenols confer the high acidity of kerosene-like fraction, as summarized in Table 12. Finally, the content of hydrocarbons within gasoline $\left(40^{\circ} \mathrm{C}<\mathrm{T}^{\mathrm{Boiling}}<175{ }^{\circ} \mathrm{C}\right)$, light kerosene $\left(175^{\circ} \mathrm{C}<\mathrm{T}^{\text {Boiling }}<200^{\circ} \mathrm{C}\right)$, and kerosene-like fraction $\left(200^{\circ} \mathrm{C}<\mathrm{T}^{\text {Boiling }}<215^{\circ} \mathrm{C}\right)$ are higher than those reported in the literature [17-19,46-48,66,70,72], proving that distillation was not only effective to diminish the acidity, but also to concentrate hydrocarbons. The classes of compounds, summation of peak areas, CAS number, and retention times of chemical compounds identified by CG-MS in bio-oil obtained by pyrolysis of Açaí seeds at $450{ }^{\circ} \mathrm{C}$ and 1.0 atmosphere, in pilot scale, as well as in distillation fractions as summarized in details in Supplementary Tables S1-S4.

Table 12. Classes of compounds and summation of peak areas of hydrocarbons and oxygenates identified by CG-MS in kerosene-like fraction $\left(200-215^{\circ} \mathrm{C}\right)$ after distillation of bio-oil obtained in pilot scale.

\begin{tabular}{cc}
\hline Classes of Chemical Compounds & wi (Area.\%) \\
\hline Alkanes & 4.20 \\
$\Sigma($ Area.\%) & \\
$\quad$ Alkenes & 2.79 \\
$\Sigma($ Area. $\%)$ & 12.88 \\
Aromatics & \\
$\Sigma($ Area.\%) & 0.96 \\
Alcohols & \\
$\Sigma($ Area.\%) & \\
\hline
\end{tabular}


Table 12. Cont.

\begin{tabular}{|c|c|}
\hline Classes of Chemical Compounds & wi (Area.\%) \\
\hline \multicolumn{2}{|l|}{ Ethers } \\
\hline$\Sigma($ Area. $\%)$ & 0.80 \\
\hline \multicolumn{2}{|l|}{ Ketones } \\
\hline$\Sigma($ Area. $\%)$ & 3.50 \\
\hline \multicolumn{2}{|l|}{ Phenols } \\
\hline$\Sigma($ Area. $\%)$ & 60.79 \\
\hline \multicolumn{2}{|l|}{ Esters } \\
\hline$\Sigma($ Area. $\%)$ & 2.06 \\
\hline \multicolumn{2}{|l|}{ Furans } \\
\hline$\Sigma($ Area. $\%)$ & 8.99 \\
\hline \multicolumn{2}{|l|}{ Aldehydes } \\
\hline$\Sigma($ Area. $\%)$ & 3.22 \\
\hline
\end{tabular}

\section{Conclusions}

The yields of bio-oil decrease with increasing reactor volume, while that of coke and gas increase. The yield of distillation fractions (gasoline, light kerosene, and kerosene-like like fractions), 77.61 (wt.\%), is higher but according than those reported in the literature for both atmospheric and vacuum conditions [17-19,21,41,46-48,53,66,70,72]. The acid values of distillation fractions increase with increasing boiling temperature. However, the acidity of gasoline-like fraction is much lower than that of raw bio-oil $(70.26 \mathrm{mg}$ $\mathrm{KOH} / \mathrm{g}$ ). The same behavior was observed for the densities, kinematic viscosities, and refractive indexes of gasoline, light kerosene, and kerosene-like like fractions with increasing boiling temperature.

The FT-IR analysis of bio-oil and distillation fraction identify the presence of hydrocarbons (alkanes, alkenes, and aromatic hydrocarbons) and oxygenates (phenols, cresols, carboxylic acids, alcohols, ethers, ketones, and furans). The bio-oil is composed of 21.52 (area.\%) hydrocarbons and 78.48 (area.\%) oxygenates. The presence of carboxylic acids, as well as phenols and cresols, is associated to the high acidity of bio-oil.

The gasoline-like fraction is composed by 64.0 (area.\%) hydrocarbons and 36.0 (area.\%) oxygenates, while light kerosene-like fraction by 66.67 (area.\%) hydrocarbons and 33.33 (area.\%) oxygenates, and kerosene-like fraction by 19.87 (area.\%) hydrocarbons and 81.13 (area.\%) oxygenates. The content of hydrocarbons within the distillation fractions are higher than those reported in the literature [17-19,46-48,66,70,72], showing that distillation was effective not only to diminish the acidity, but also to concentrate hydrocarbons.

Supplementary Materials: The following are available online at https:/ /www.mdpi.com/article/ 10.3390/en14133713/s1, Table S1: Classes of compounds, summation of peak areas, CAS number, and retention times of chemical compounds identified by CG-MS in bio-oil obtained by pyrolysis of Açaí seeds at $450{ }^{\circ} \mathrm{C}$ and 1.0 atmosphere, in pilot scale., Table S2: Classes of compounds, summation of peak areas, CAS number, and retention times of chemical compounds identified by CG-MS in gasoline-like fraction $\left(40-175^{\circ} \mathrm{C}\right)$ after distillation of bio-oil obtained by pyrolysis of Açaí seeds at $450{ }^{\circ} \mathrm{C}$ and 1.0 atmosphere, in pilot scale., Table S3: Classes of compounds, summation of peak areas, CAS number, and retention times of chemical compounds identified by CG-MS in light kerosenelike fraction $\left(175-200{ }^{\circ} \mathrm{C}\right)$ after distillation of bio-oil obtained by pyrolysis of Açaí seeds at $450{ }^{\circ} \mathrm{C}$ and 1.0 atmosphere, in pilot scale., Table S4: Classes of compounds, summation of peak areas, CAS number, and retention times of chemical compounds identified by CG-MS in kerosene-like fraction $\left(200-215^{\circ} \mathrm{C}\right)$ after distillation of bio-oil obtained by pyrolysis of Açaí seeds at $450^{\circ} \mathrm{C}$ and 1.0 atmosphere, in pilot scale.

Author Contributions: Investigation, Methodology, Formal analysis and Writing original draft preparation, D.A.R.d.C.; Formal analysis and Software, M.C.S.; Formal analysis, Software, and Visualization, H.d.S.A.; Investigation and Validation, H.J.d.S.R.; Investigation and Methodology, L.H.H.G.; Chemical analysis, S.J.B.; Chemical analysis, L.P.B.; Resources and Chemical analysis, S.D.J.; 
Co-supervision and Resources, L.E.P.B.; Supervision, Conceptualization, and Data curation, N.T.M. All authors have read and agreed to the published version of the manuscript.

Funding: This research was partially funded by CNPq-Brazil, grant number: 207325/2014-6.

Informed Consent Statement: Not applicable.

Data Availability Statement: Data available in a publicly accessible repository that does not issue DOIs (https:/ / drive.google.com/file/d/1mOxMKWsXkZDLVfnnsrWc6NsHLheW4u1p/view, accessed on 12 May 2021).

Acknowledgments: I would like to acknowledge and dedicate this research in memory to $>$ Hélio da Silva Almeida, Professor at the Faculty of Sanitary and Environmental Engineering/UFPa, who passed away in 13 March 2021. His contagious joy, dedication, intelligence, honesty, seriousness, and kindness will always be remembered in our hearts.

Conflicts of Interest: The authors declare no conflict of interest.

\section{References}

1. Scherwinski-Pereira, J.E.; Guedes, R.D.S.; Da Silva, R.A.; Fermino, P.C.P.; Luis, Z.G.; Freitas, E.D.O. Somatic embryogenesis and plant regeneration in açaí palm (Euterpe oleracea). Plant Cell Tissue Organ Cult. (PCTOC) 2012, 109, 501-508. [CrossRef]

2. Schauss, A.G.; Wu, X.; Prior, R.L.; Ou, B.; Patel, D.; Huang, D.; Kababick, J.P. Phytochemical and Nutrient Composition of the Freeze-Dried Amazonian Palm Berry, Euterpe oleraceaeMart. (Acai). J. Agric. Food Chem. 2006, 54, 8598-8603. [CrossRef] [PubMed]

3. Sabbe, S.; Verbeke, W.; Deliza, R.; Matta, V.; Van Damme, P. Effect of a health claim and personal characteristics on consumer acceptance of fruit juices with different concentrations of açaí (Euterpe oleracea Mart.). Appetite 2009, 53, 84-92. [CrossRef] [PubMed]

4. Pacheco-Palencia, L.A.; Duncan, C.E.; Talcott, S.T. Phytochemical composition and thermal stability of two commercial açai species, Euterpe oleracea and Euterpe precatoria. Food Chem. 2009, 115, 1199-1205. [CrossRef]

5. Brondizio, E.S.; Safar, C.A.; Siqueira, A.D. The urban market of Açaí fruit (Euterpe oleracea Mart.) and rural land use change: Ethnographic insights into the role of price and land tenure constraining agricultural choices in the Amazon estuary. Urban Ecosyst. 2002, 6, 67-97. [CrossRef]

6. Dos Santos Bentes, E.; Oyama Homma, A.K.; Nunes dos Santos, C.A. Exportações de Polpa de Açaí do Estado do Pará: Situação Atual e Perspectivas. In: Anais Congresso da Sociedade Brasileira de Economia, Administração e Sociologia Rural, 55, Santa Maria, RS-Brazil. 2017. Available online: https:/ / www.researchgate.net/publication/319465735_Exportacoes_de_Polpa_de_ Acai_do_Estado_do_Para_Situacao_Atual_e_Perspectivas (accessed on 5 August 2020).

7. Almeida, A.V.D.C.; Melo, I.M.; Pinheiro, I.S.; Freitas, J.F. Appreciation of acai core of a pulp producer from Ananindeua/PA: Proposal of reverse channel structure oriented by NPSW and reverse logistics. Rev. Gestão Produção Operações Sist. 2017, 12, 59-83. [CrossRef]

8. Townsend, C.R.; de Lucena Costa, N.; de Araújo Pereira, R.G.; Clóvis, C. Diesel Senger. Características Químico-Bromatológica do Caroço de Açaí. COMUNICADO TÉCNICO No 193 (CT/193), EMBRAPA-CPAF Rondônia, ago./01, 1-5. ISSN 0103-9458. Available online: https:/ / ainfo.cnptia.embrapa.br/digital/bitstream/item/100242/1/Cot193-acai.pdf (accessed on 5 August 2020).

9. Fioravanti, C. Açaí: Do pé para o lanche. Rev. Pesqui. Fapesp. 2013, 203, 64-68. Available online: http:/ / revistapesquisa.fapesp. br/2013/01/11/folheie-a-edicao-203/ (accessed on 5 August 2020).

10. De Santana, A.C.; De Santana, Á.L.; De Santana, Á.L.; Dos Santos, M.A.S.; De Oliveira, C.M. Análise discriminante múltipla do mercado varejista de açaí em Belém do Pará. Rev. Bras. Frutic. 2014, 36, 532-541. [CrossRef]

11. Pessoa, J.D.C.; Silva, P.V.D. Effect of temperature and storage on açaí (Euterpe oleracea) fruit water uptake: Simulation of fruit transportation and pre-processing. Fruits 2007, 62, 295-302. [CrossRef]

12. Cordeiro, M.A. Estudo da Hidrólise Enzimática do Caroço de açaí (Euterpe Oleracea, Mart) para a Produção de Etanol. Dissertação de Mestrado, Programa de Pós-Graduação em Engenharia Química, UFPA-Brazil. Marcio de Andrade Cordeiro. 2016. Available online: https:/ / ppgeq.propesp.ufpa.br/ARQUIVOS/dissertacoes/2016/M\%C3\%A1rcio\%20de\%20Andrade\%20Cordeiro/M\% C3\%A1rcio_Disserta\%C3\%A7\%C3\%A3o_Defesa.pdf (accessed on 5 August 2020).

13. Da Fonseca, T.R.; de Amorim Silva, T.; Alecrim, M.M.; da Cruz Filho, R.F.; Teixeira, M.F. Cultivation and nutritional studies of an edible mushroom from North Brazil. Afr. J. Microbiol. Res. 2015, 9, 1814-1822.

14. Kabacknik, A.; Roger, H. Determinação do Poder Calorífico do Caroço do açaí em três Distintas Umidades. In Proceedings of the 38th Congresso Brasileiro de Química, São Luiz, MA, Brazil, 21-25 Septembar 1998.

15. Altman, R.F.A. O Caroço de açaí (Euterpe Oleracea, Mart); Boletim Técnico do Instituto Agronômico do Norte: Belém, Brasil, 1956; Volume 31, pp. 109-111. Available online: https://www.bdpa.cnptia.embrapa.br/consulta/busca?b=ad\&biblioteca=vazio\& busca=autoria:"ALTMAN,\%20R.\%20F.\%20A." (accessed on 5 August 2020).

16. Özçimen, D.; Ersoy-Meriçboyu, A. Characterization of biochar and bio-oil samples obtained from carbonization of various biomass materials. Renew. Energy 2010, 35, 1319-1324. [CrossRef] 
17. Adjaye, J.D.; Sharma, R.K.; Bakhshi, N.N. Characterization and stability analysis of wood-derived bio-oil. Fuel Process. Technol. 1992, 31, 241-256. [CrossRef]

18. Carazza, F.; Rezende, M.E.A.; Pasa, V.M.D.; Lessa, A. Fractionation of wood tar. Proc. Adv. Thermochem. Biomass Convers. 1994, 2,465 .

19. Adjaye, J.; Bakhshi, N. Production of hydrocarbons by catalytic upgrading of a fast pyrolysis bio-oil. Part I: Conversion over various catalysts. Fuel Process. Technol. 1995, 45, 161-183. [CrossRef]

20. Xu, B.J.; Lu, N. Experimental research on the bio-oil derived from biomass pyrolysis liquefaction. Trans. Chin. Soc. Agric. Eng. $1999,15,177-181$.

21. Boucher, M.E.; Chaala, A.; Roy, C. Bio-oils obtained by vacuum pyrolysis of softwood bark as a liquid fuel for gas turbines. Part I: Properties of bio-oil and its blends with methanol and a pyrolytic aqueous phase. Biomass Bioenergy 2000, 19, 337-350. [CrossRef]

22. Oasmaa, A.; Kuoppala, E.; Gust, S.; Solantausta, Y. Fast Pyrolysis of Forestry Residue. 1. Effect of Extractives on Phase Separation of Pyrolysis Liquids. Energy Fuels 2003, 17, 1-12. [CrossRef]

23. Czernik, S.; Bridgwater, A.V. Overview of applications of biomass fast pyrolysis oil. Energy Fuels 2004, 18, 590-598. [CrossRef]

24. Mohan, D.; Pittman, C.U., Jr.; Steelee, P.H. Pyrolysis of wood/biomass for bio-oil: A critical review. Energy Fuels 2006, 20, 848-889. [CrossRef]

25. Yu, F.; Deng, S.; Chen, P.; Liu, Y.; Wan, Y.; Olson, A.; Kittelson, D.; Ruan, R. Physical and Chemical Properties of Bio-Oils from Microwave Pyrolysis of Corn Stover. Appl. Biochem. Biotecnol. 2007, 136-140, 957-970. [CrossRef]

26. Zhang, Q.; Chang, J.; Wang, T.; Xu, Y. Review of biomass pyrolysis oil properties and upgrading research. Energy Convers. Manag. 2007, 48, 87-92. [CrossRef]

27. Boateng, A.A.; Mullen, C.A.; Goldberg, N.; Hicks, K.B. Production of bio-oil from alfalfa stems by fluidized-bed fast pyrolysis. Ind. Eng. Chem. Res. 2008, 47, 4115-4122. [CrossRef]

28. Lu, Q.; Yang, X.L.; Zhu, X.F. Analysis on chemical and physical properties of bio-oil pyrolyzed from rice husk. J. Anal. Appl. Pyrolysis 2008, 82, 191-198. [CrossRef]

29. Junming, X.; Jianchun, J.; Yunjuan, S.; Yanju, L. Bio-oil upgrading by means of ethyl ester production in reactive distillation to remove water and to improve storage and fuel characteristics. Biomass Bioenergy 2008, 32, 1056-1061. [CrossRef]

30. Guo, Z.; Wang, S.; Zhu, Y.; Luo, Z.; Cen, K. Separation of acid compounds for refining biomass pyrolysis oil. J. Fuel Chem. Technol. 2009, 7, 49-52. [CrossRef]

31. Vispute, T.P.; Huber, G.W. Production of hydrogen, alkanes and polyols by aqueous phase processing of wood-derived pyrolysis oils. Green Chem. 2009, 11, 1433-1445. [CrossRef]

32. Song, Q.-H.; Nie, J.-Q.; Ren, M.-G.; Guo, Q.-X. Effective Phase Separation of Biomass Pyrolysis Oils by Adding Aqueous Salt Solutions. Energy Fuels 2009, 23, 3307-3312. [CrossRef]

33. Wang, S.; Gu, Y.; Liu, Q.; Yao, Y.; Guo, Z.; Luo, Z.; Cen, K. Separation of bio-oil by molecular distillation. Fuel Process. Technol. 2009, 90, 738-745. [CrossRef]

34. Oasmaa, A.; Elliott, D.C.; Korhonen, J. Acidity of Biomass Fast Pyrolysis Bio-oils. Energy Fuels 2010, 24, 6548-6554. [CrossRef]

35. De Castro, D.A.R. Processo de Produção de Bio-Óleo e Bio-Adsorventes via Pirólise das Sementes do Açaí (Euterpe oleraceae, Mart). Ph.D. Thesis, PRODERNA, UFPa, Belém, Brazil, 2019.

36. Guo, X.; Wang, S.; Guo, Z.; Liu, Q.; Luo, Z.; Cen, K. Pyrolysis characteristics of bio-oil fractions separated by molecular distillation. Appl. Energy 2010, 87, 2892-2898. [CrossRef]

37. Guo, Z.; Wang, S.; Gu, Y.; Xu, G.; Li, X.; Luo, Z. Separation characteristics of biomass pyrolysis oil in molecular distillation. Sep. Purif. 2010, 76, 52-57. [CrossRef]

38. Suota, M.J.; Simionatto, E.L.; Scharf, D.R.; Meier, H.F.; Wiggers, V.R. Esterification, Distillation, and Chemical Characterization of Bio-Oil and Its Fractions. Energy Fuels 2019, 33, 9886-9894. [CrossRef]

39. Nam, H.; Choi, J.; Capareda, S.C. Comparative study of vacuum and fractional distillation using pyrolytic microalgae (Nannochloropsis oculata) bio-oil. Algal Res. 2016, 17, 87-96. [CrossRef]

40. Christensen, E.D.; Chupka, G.M.; Smurthwaite, J.L.T.; Alleman, T.L.; Lisa, K.; Franz, J.A.; Elliott, D.C.; Mc Cormick, R.L. Analysis of oxygenated compounds in hydrotreated biomass fast pyrolysis oil distillate fractions. Energy Fuels 2011, 25, 5462-5471. [CrossRef]

41. Zheng, J.-L.; Wei, Q. Improving the quality of fast pyrolysis bio-oil by reduced pressure distillation. Biomass Bioenergy 2011, 35, 1804-1810. [CrossRef]

42. Pollard, A.; Rover, M.; Brown, R.C. Characterization of bio-oil recovered as stage fractions with unique chemical and physical properties. J. Anal. Appl. Pyrolysis 2012, 93, 129-138. [CrossRef]

43. Shah, A.; Darr, M.J.; Dalluge, D.; Medic, D.; Webster, K.; Brown, R.C. Physicochemical properties of bio-oil and biochar produced by fast pyrolysis of stored single-pass corn stover and cobs. Bioresour. Technol. 2012, 125, 348-352. [CrossRef] [PubMed]

44. Imam, T.; Capareda, S. Characterization of bio-oil, syngas and bio-char from switch grass pyrolysis at various temperatures. J. Anal. Appl. Pyrolysis 2012, 93, 170-177. [CrossRef]

45. Xiu, S.; Shahbazi, A. Bio-oil production and upgrading research: A review. Renew. Sustain. Energy Rev. 2012, 16, 4406-4414. [CrossRef]

46. Majhi, A.; Sharma, Y.K.; Naik, D.V. Blending optimization of Hempel distilled bio-oil with commercial diesel. Fuel 2012, 96, 264-269. [CrossRef] 
47. Zhang, X.-S.; Yang, G.-X.; Jiang, H.; Liu, W.-J.; Ding, H.-S. Mass production of chemicals from biomass-derived oil by directly atmospheric distillation coupled with co-pyrolysis. Sci. Rep. 2013, 3, srep01120. [CrossRef] [PubMed]

48. Capunitan, J.A.; Capareda, S.C. Characterization and separation of corn stover bio-oil by fractional distillation. Fuel 2013, 112, 60-73. [CrossRef]

49. Sun, Y.; Gao, B.; Yao, Y.; Fang, J.; Zhang, M.; Zhou, Y.; Chen, H.; Yang, L. Effects of feedstock type, production method, and pyrolysis temperature on biochar and hydrochar properties. Chem. Eng. J. 2014, 240, 574-578. [CrossRef]

50. Yang, H.; Yao, J.; Chen, G.; Ma, W.; Yan, B.; Qi, Y. Overview of Upgrading of Pyrolysis Oil of Biomass. Energy Procedia 2014, 61, 1306-1309. [CrossRef]

51. Gooty, A.T.; Li, D.; Berruti, F.; Briens, C. Kraft-lignin pyrolysis and fractional condensation of its bio-oil vapors. J. Anal. Appl. Pyrolysis 2014, 106, 33-40. [CrossRef]

52. Biradar, C.H.; Subramanian, K.A.; Dastidar, M.G. Production and fuel upgrading of pyrolysis bio-oil Jatropha Curcas de-oiled seed cake. Fuel 2014, 119, 81-89. [CrossRef]

53. Elkasabi, Y.; Mullen, C.A.; Boateng, A.A. Distillation and isolation of commodity chemicals from bio-oil made by tail-gas reactive pyrolysis. Sustain. Chem. Eng. 2014, 2, 2042-2052. [CrossRef]

54. Gooty, A.T.; Li, D.; Briens, C.; Berruti, F. Fractional condensation of bio-oil vapors produced from birch bark pyrolysis. Sep. Purif. Technol. 2014, 124, 81-88. [CrossRef]

55. Wang, S.; Cai, Q.; Wang, X.; Zhang, L.; Wang, Y.; Luo, Z. Biogasoline Production from the Co-cracking of the Distilled Fraction of Bio-oil and Ethanol. Energy Fuels 2013, 28, 115-122. [CrossRef]

56. Papari, S.; Hawboldt, K. A review on the pyrolysis of woody biomass to bio-oil: Focus on kinetic models. Renew. Sustain. Energy Rev. 2015, 52, 1580-1595. [CrossRef]

57. Kambo, H.S.; Dutta, A. A comparative review of biochar and hydro-char in terms of production, physico-chemical properties and applications. Renew. Sustain. Energy Rev. 2015, 45, 359-378. [CrossRef]

58. Kumar, S.; Lange, J.-P.; Van Rossum, G.; Kersten, S.R. Bio-oil fractionation by temperature-swing extraction: Principle and application. Biomass Bioenergy 2015, 83, 96-104. [CrossRef]

59. Elkasabi, Y.; Boateng, A.A.; Jackson, M.A. Upgrading of bio-oil distillation bottoms into biorenewable calcined coke. Biomass Bioenergy 2015, 81, 415-423. [CrossRef]

60. Elkasabi, Y.; Mullen, C.A.; Jackson, M.A.; Boateng, A.A. Characterization of fast-pyrolysis bio-oil distillation residues and their potential applications. J. Anal. Appl. Pyrolysis 2015, 114, 179-186. [CrossRef]

61. Kanaujia, P.K.; Naik, D.V.; Tripathi, D.; Singh, R.; Poddar, M.K.; Siva Kumar Konathala, L.N.; Sharma, Y.K. Pyrolysis of Jatropha Curcas seed cake followed by optimization of liquid-liquid extraction procedure for the obtained bio-oil. Anal. Appl. Pyrolysis 2016, 118, 202-224. [CrossRef]

62. Kan, T.; Strezov, V.; Evans, T.J. Lignocellulosic biomass pyrolysis: A review of product properties and effects of pyrolysis parameters. Renew. Sustain. Energy Rev. 2016, 57, 1126-1140. [CrossRef]

63. Cai, J.; Banks, S.W.; Yang, Y.; Darbar, S.; Bridgwater, T. Viscosity of Aged Bio-oils from Fast Pyrolysis of Beech Wood and Miscanthus: Shear Rate and Temperature Dependence. Energy Fuels 2016, 30, 4999-5004. [CrossRef]

64. Zheng, Y.; Wang, F.; Yang, X.; Huang, Y.; Liu, C.; Zheng, Z.; Gu, J. Study on aromatics production via the catalytic pyrolysis vapor upgrading of biomass using metal-loaded modified H-ZSM-5. J. Anal. Appl. Pyrolysis 2017, 126, 169-179. [CrossRef]

65. Johansson, A.-C.; Iisa, K.; Sandström, L.; Ben, H.; Pilath, H.; Deutch, S.; Wiinikka, H.; Öhrman, O.G. Fractional condensation of pyrolysis vapors produced from Nordic feedstocks in cyclone pyrolysis. J. Anal. Appl. Pyrolysis 2017, 123, 244-254. [CrossRef]

66. Kuo, H.P.; Hou, B.R.; Huang, A.N. The influence of the gas fluidization velocity on the properties of bio-oils from fluidized bed pyrolizer with in-line distillation. Appl. Energy 2017, 194, 279-286. [CrossRef]

67. Guedes, R.E.; Luna, A.S.; Torres, A.R. Operating parameters for bio-oil production in biomass pyrolysis: A review. J. Anal. Appl. Pyrolysis 2018, 129, 134-149. [CrossRef]

68. Dhyani, V.; Bhaskar, T. A comprehensive review on the pyrolysis of lignocellulosic biomass. Renew. Energy 2018, 129, 695-716. [CrossRef]

69. Cai, W.; Liu, R.; He, Y.; Chai, M.; Cai, J. Bio-oil production from fast pyrolysis of rice husk in a commercial-scale plant with a downdraft circulating fluidized bed reactor. Fuel Process. Technol. 2018, 171, 308-317. [CrossRef]

70. Huang, A.-N.; Hsu, C.-P.; Hou, B.-R.; Kuo, H.-P. Production and separation of rice husk pyrolysis bio-oils from a fractional distillation column connected fluidized bed reactor. Powder Technol. 2018, 323, 588-593. [CrossRef]

71. Rahman, S.; Helleur, R.; MacQuarrie, S.; Papari, S.; Hawboldt, K. Upgrading and isolation of low molecular weight compounds from bark and softwood bio-oils through vacuum distillation. Sep. Purif. Technol. 2018, 194, 123-129. [CrossRef]

72. Yuan, X.; Sun, M.; Wang, C.; Zhu, X. Full temperature range study of rice husk bio-oil distillation: Distillation characteristics and product distribution. Sep. Purif. Technol. 2021, 263, 118382. [CrossRef]

73. De Castro, D.A.R.; Ribeiro, H.J.D.S.; Ferreira, C.C.; Cordeiro, M.D.A.; Guerreiro, L.H.H.; Pereira, A.M.; Dos Santos, W.G.; Santos, M.C.; De Carvalho, F.B.; Junior, J.O.C.S.; et al. Fractional Distillation of Bio-Oil Produced by Pyrolysis of Açaí (Euterpe oleracea) Seeds. In Fractionation; Ibrahim, H.A.-H., Ed.; IntechOpen: London, UK, 2019. [CrossRef]

74. De Andrade Cordeiro, M.; de Almeida, O.; de Castro, D.A.; da Silva Ribeiro, H.J.; Machado, N.T. Produção de Etanol através da Hidrólise Enzimática do Caroço de Açaí (Euterpe oleracea, Mart.). Rev. Bras. Energ. Renov. 2019, 8, $122-152$.

75. Acid-Insoluble Lignin in Wood and Pulp; Tappi Method T 222 Om-06; Tappi Press: Atlanta, GA, USA, 2006. 
76. Buffiere, P.; Loisel, D. Dosage des fibres Van Soest; Weened, Laboratoire de Biotechnologie de l'Environnement, INRA: Narbonne, France, 2007; pp. 1-14.

77. Almeida, H.D.S.; Corrêa, O.; Eid, J.; Ribeiro, H.; De Castro, D.; Pereira, M.; Pereira, L.; Aâncio, A.D.A.; Santos, M.; Da Mota S.; et al. Performance of thermochemical conversion of fat, oils, and grease into kerosene-like hydrocarbons in different production scales. J. Anal. Appl. Pyrolysis 2016, 120, 126-143. [CrossRef]

78. Da Mota, S.A.; Mancio, A.A.; Lhamas, D.E.; De Abreu, D.H.; Da Silva, M.S.; Dos Santos, W.G.; De Castro, D.A.; De Oliveira, R.M.; Araújo, M.E.; Borges, L.E.; et al. Production of green diesel by thermal catalytic cracking of crude palm oil (Elaeis guineensis Jacq) in a pilot plant. J. Anal. Appl. Pyrolysis 2014, 110, 1-11. [CrossRef]

79. Ferreira, C.C.; Costa, E.C.; de Castro, D.A.; Pereira, M.S.; Mâncio, A.A.; Santos, M.C.; Lhamas, D.E.; Da Mota, S.A.; Leão, A.C.; Duvoisin, S., Jr.; et al. Deacidification of organic liquid products by fractional distillation in laboratory and pilot scales. J. Anal. Appl. Pyrolysis 2017, 127, 468-489. [CrossRef]

80. Seshadri, K.S.; Cronauer, D.C. Characterization of coal-derived liquids by 13C N.M.R. and FT-IR Spectroscopy. Fuel 1983, 62, 1436-1444. [CrossRef]

81. Abnisa, F.; Arami-Niya, A.; Daud, W.M.; Sahu, J.N. Characterization of Bio-oil and Bio-char from Pyrolysis of Palm Oil Wastes. BioEnergy Res. 2013, 6, 830-840. [CrossRef]

82. Tanneru, S.K.; Parapati, D.R.; Steele, P.H. Pretreatment of bio-oil followed by upgrading via esterification to boiler fuel. Energy 2014, 73, 214-220. [CrossRef]

83. Garcia-Perez, M.; Chaala, A.; Roy, C. Vacuum pyrolysis of sugarcane bagasse. J. Anal. Appl. Pyrolysis 2002, 65, 111-136. [CrossRef]

84. Nolte, M.W.; Liberatore, M.W. Viscosity of Biomass Pyrolysis Oils from Various Feedstocks. Energy Fuels 2010, 24, 6601-6608. [CrossRef]

85. Ba, T.; Chaala, A.; Garcia-Perez, M.; Rodrigue, D.; Roy, C. Colloidal properties of bio-oils obtained by vacuum pyrolysis of softwood bark. Characterization of water-soluble and water-insoluble fractions. Energy Fuels 2004, 18, 704-712. [CrossRef] 